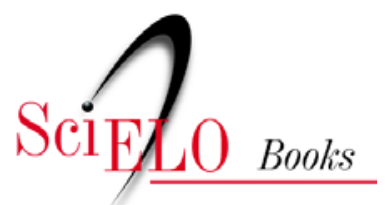

\title{
3 - Dinâmica dos investimentos no subsistema de base química e biotecnológica
}

\author{
Carlos A. Grabois Gadelha (cood.)
}

\section{SciELO Books / SciELO Livros / SciELO Libros}

GADELHA, CAG., cood. Dinâmica dos investimentos no subsistema de base química e biotecnológica. In: A dinâmica do sistema produtivo da saúde: inovação e complexo econômicoindustrial [online]. Rio de Janeiro: Editora FIOCRUZ, 2012, pp. 47-103. ISBN: 978-85-7541-593-1. Available from: doi: $10.7476 / 9788575415931.0004$. Also available in ePUB from: http://books.scielo.org/id/6t3hs/epub/gadelha-9788575415931.epub

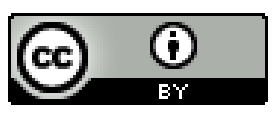

All the contents of this work, except where otherwise noted, is licensed under a Creative Commons Attribution 4.0 International license.

Todo o conteúdo deste trabalho, exceto quando houver ressalva, é publicado sob a licença Creative Commons Atribição 4.0. 


\section{Dinâmica dos Investimentos no Subsistema de Base Química e Biotecnológica}

O Subsistema de Base Química e Biotecnológica envolve um conjunto de segmentos produtivos que se destacam tanto por sua relevância econômica como por sua importância no domínio de novas tecnologias em áreas estratégicas para o país. Dentre as atividades que o integram, encontra-se a produção de medicamentos, fármacos, vacinas, hemoderivados, soros e reagentes para diagnóstico. Não obstante a existência de especificidades nos padrões de competição e inovação tecnológicas nos diferentes segmentos, a dinâmica competitiva e inovativa deste subsistema é claramente liderada pela indústria farmacêutica, que passa, de forma crescente, a ser o âmbito principal e determinante da geração e difusão de inovações de base química e biotecnológica.

Em 2010, o mercado farmacêutico brasileiro ocupava a oitava posição no ranking mundial da indústria farmacêutica e respondia por um faturamento de $\mathrm{R} \$ 36,25$ bilhões (Sindusfarma, 2012). Apesar do claro predomínio das grandes empresas multinacionais no mercado nacional, verificou-se, ao longo das últimas décadas, um aumento considerável na participação de empresas brasileiras no mercado farmacêutico nacional. A expansão de empresas farmacêuticas brasileiras no mercado nacional esteve particularmente associada à consolidação do segmento de medicamentos genéricos no país e representou importante ponto de inflexão na trajetória de crescimento da indústria farmacêutica nacional. Também o aumento sustentado nos gastos públicos com saúde no Brasil no decorrer dos últimos anos constitui um importante fator de estímulo à expansão dos investimentos na indústria farmacêutica nacional.

No que se refere ao comércio exterior, entretanto, a situação de desequilíbrio estrutural da balança comercial relativa aos segmentos mais intensivos em conhecimentos da indústria farmacêutica parece se ampliar progressivamente. Em 2011, o déficit comercial relacionado ao Subsistema de Base Química e Biotecnológica 
do Complexo Econômico-Industrial da Saúde (CEIS) atingiu o montante de US\$ 7.6 bilhões, $65 \%$ dos quais - o equivalente a US\$ 4.9 bilhões - estiveram relacionados com a importação de fármacos e medicamentos. Dentre os demais segmentos, $22 \%$ ou US\$ 1.7 bilhão foram decorrentes do déficit com a importação de hemoderivados, $7 \%$ ou US $\$ 500$ milhões decorrentes da importação de vacinas e os restantes $7 \%$, oriundos da importação de soros e reagentes para diagnóstico. Tal situação, por um lado, revela a vulnerabilidade do sistema nacional de saúde e, por outro, explicita a necessidade de se associar o aumento da capacidade produtiva nacional com estratégias ativas de inovação em torno de novas plataformas tecnológicas baseadas nos avanços da biotecnologia, da química fina e dos produtos naturais.

Quanto à articulação do Subsistema de Base Química e Biotecnológica com os demais subsistemas que integram o CEIS, mudanças recentes nos padrões de investimento no Subsistema de Serviços de Saúde, particularmente aquelas associadas ao aumento dos gastos em prevenção (como serviços de diagnóstico e programas de vacinação), exercem elevado impacto sobre as perspectivas e padrões de investimento da indústria farmacêutica e farmoquímica. Adicionalmente, é possível destacar a crescente articulação entre a indústria farmacêutica e o setor de serviços de saúde no esforço de pesquisa.

\section{DINÂMICA GLOBAL DO INVESTIMENTO}

\section{Panorama Global e Padrões de Concorrência}

A indústria farmacêutica internacional se caracteriza como um oligopólio diferenciado, baseado nas ciências e com elevadas barreiras à entrada de novos concorrentes, associadas particularmente ao papel do marketing. As empresas que lideram o setor são de grande porte e atuam de forma globalizada no mercado mundial, havendo interdependência entre as estratégias perseguidas no interior de cada grupo nos distintos mercados nacionais e entre os diferentes competidores. A liderança de mercado é exercida em segmentos de mercado particulares (classes terapêuticas, entre outros recortes possíveis), mediante diferenciação de produtos. As barreiras à entrada nessa indústria são, assim, decorrentes das economias de escala relacionadas às atividades de Pesquisa e Desenvolvimento $(P \& D)$ e de marketing, não sendo predominante a competição via preços (Gadelha, 1990, 2002). Como decorrência, a indústria, especialmente no caso dos medicamentos éticos, ${ }^{6}$ apresenta baixa elasticidade-preço da demanda (Bastos, 2005), marcando, em termos estruturais (e não apenas comportamentais), sua natureza oligopólica. O principal instrumento da indústria de apropriação de resultados oriundos de seus esforços de P\&D é a patente, que garante um monopólio temporário de vendas (Capanema, 2006).

\footnotetext{
${ }^{6}$ No Brasil, a participação de medicamentos éticos situa-se em torno de $90 \%$ do mercado, o que revela o papel dos médicos na demanda setorial (Bastos, 2005).
} 
No decorrer das duas últimas décadas e meia, a indústria farmacêutica conheceu um crescimento espetacular, marcado, entre outros aspectos, por concentração industrial, lucros excepcionais e combinação de crescimento no consumo de medicamentos com aumento de preços (Angell, 2007). Na raiz desse processo destacam-se os seguintes elementos:

- Exploração de novos caminhos científicos e tecnológicos que favorecessem a retomada da geração de inovações em virtude do esgotamento do potencial a partir da predominância do paradigma tecnológico na segunda metade do século passado.

- Impacto da biotecnologia não somente na inovação em processos de P\&D, mas também em produtos.

- Pressão dos medicamentos genéricos, em um cenário de expiração de patentes em medicamentos líderes em vendas.

- Diversas iniciativas no âmbito das políticas públicas de Ciência e Tecnologia (C\&T) de reforço das capacitações inovativas nacionais que favoreceram a indústria farmacêutica (impacto do Bayh-Dole Act, da Lei Hatch-Waxman, entre outras).

- Entrada em vigor, no fim da década de 1990, do Acordo de Propriedade Intelectual (Trips), no âmbito da Organização Mundial do Comércio (OMC), que significou o reconhecimento de patentes farmacêuticas por grande número de países, entre eles o Brasil. Diante do acirramento da concorrência, o acordo resultou em espaços restritos de atuação nacional e eliminação de iniciativas empresariais farmacêuticas e biotecnológicas em diversos países (Capanema, 2006; Morel, 2007).

- O efeito combinado do novo approach de C\&T e do novo ambiente regulatório significou custos de $P \& D$ crescentes.

- Pressão pelo controle dos gastos públicos com a saúde e exercício do poder de compra das organizações públicas e privadas de saúde visando à redução de custos de cobertura e, concomitantemente, do preço dos remédios.

As empresas farmacêuticas responderam a esses desafios adotando, entre outras, estratégias de gestão baseadas em: implementação de sistemas de controle que combinavam centralização do processo decisório com descentralização mundial de atividades produtivas e de $\mathrm{P} \& \mathrm{D}$; obtenção de economias de escala e de escopo globais mediante aquisições e fusões; diversificação das empresas que passaram a produzir genéricos e produtos não éticos; utilização do domínio de mercado para aquisição externa de tecnologia via acordos de licenciamento, contratos de P\&D, joint ventures, alianças e aquisição de empresas de biotecnologia. Esse reposicionamento estratégico não mudou, na essência, a estrutura da indústria nem o padrão de competição vigente. Os novos desafios trazidos pelo paradigma da biotecnologia estão vinculados 
à revitalização das empresas líderes e ao fortalecimento do modus operandi da indústria (Gadelha, 1990).

A Tabela 11 apresenta as vinte principais empresas mundiais do setor farmacêutico em termos de vendas e investimentos em P\&D, grande parte das quais está sediada nos Estados Unidos (EUA). Outros países com liderança expressiva no setor são: França, Suíça, Reino Unido, Alemanha e Japão.

Tabela 11 - Ranking das maiores empresas farmacêuticas mundiais - 2010

\begin{tabular}{|c|c|c|c|c|c|}
\hline RANKING & EMPRESA (MATRIZ) & SEDE DA MATRIZ & $\begin{array}{c}\text { VENDAS EM } 2010 \\
\text { (US\$ BILHÕES) }\end{array}$ & $\begin{array}{l}\text { GASTOS COM P\&D } \\
\text { (US\$ MLLHÖES) }\end{array}$ & $\begin{array}{l}\text { GASTOS EM P\&D } \\
\text { (\% / VENDAS) }\end{array}$ \\
\hline 1 & Pfizer & EUA & 58.5 & 9.413 & 16,1 \\
\hline 2 & Novartis & Suíça & 42.0 & 7.100 & 16,9 \\
\hline 3 & Sanofi-Aventis & França & 40.3 & 5.147 & 12,8 \\
\hline 4 & Merck & EUA & 39.8 & 11.000 & 27,6 \\
\hline 5 & Roche & Suíça & 39.1 & 8.612 & 22,0 \\
\hline 6 & GlaxoSmithKline & Reino Unido & 36.2 & 6.126 & 16,9 \\
\hline 7 & AstraZeneca & Reino Unido & 33.3 & 4.200 & 12,6 \\
\hline 8 & Johnson \& Johnson & EUA & 22.4 & 4.432 & 19,8 \\
\hline 9 & Eli Lilly & EUA & 21.1 & 4.880 & 23,1 \\
\hline 10 & Abbott & EUA & 19.9 & 3.724 & 18,7 \\
\hline 11 & Bristol-Myers Squibb & EUA & 19.5 & 3.566 & 18,3 \\
\hline 12 & Teva & Israel & 16.1 & 933 & 5,8 \\
\hline 13 & Amgen & EUA & 14.7 & 2.894 & 19,7 \\
\hline 14 & Bayer & Alemanha & 14.5 & 2.320 & 16,0 \\
\hline 15 & Takeda & Japão & 14.2 & 3.198 & 22,5 \\
\hline 16 & Boehringer Ingelheim & Alemanha & 12.9 & 3.056 & 23,7 \\
\hline 17 & Novo Nordisk & Dinamarca & 10.8 & 1.709 & 15,8 \\
\hline 18 & Astellas & Japão & 10.5 & 2.109 & 20,1 \\
\hline 19 & Daiichi Sankyo & Japão & 9.8 & 2.124 & 21,7 \\
\hline 20 & Eisai & Japão & 8.4 & 1.932 & 23,0 \\
\hline
\end{tabular}

Fonte: PharmExec.com, 2010.

Características marcantes do setor farmacêutico são o elevado grau de internacionalização das empresas e a crescente concentração industrial no decorrer das últimas décadas. No fim da década de 1990 as dez maiores empresas farmacêuticas 
respondiam conjuntamente por 34\% das vendas globais do setor. Já em 2009 as dez maiores empresas multinacionais da indústria farmacêutica eram responsáveis por $45 \%$ das vendas totais, o que evidencia um movimento histórico de forte concentração (Vargas et al., 2010). O aumento na concentração industrial do setor resultou de um intenso processo de fusões e aquisições que a indústria farmacêutica conheceu ao longo da década de 1990 e até os dias de hoje, o que acarretou um aumento significativo na participação dos maiores grupos no mercado mundial. Citam-se, a título de exemplo, a aquisição da Wellcome pela Glaxo em 1996, dando origem à Glaxo Wellcome; a fusão, em 1996, da Sandoz e Ciba formando a Novartis; a constituição da Aventis, empresa resultante da fusão, em 1999, da Hoechst com a Rhône-Poulenc. Em 2004, ocorreu a fusão da Aventis com a Sanofi-Synthélabo, formando a SanofiAventis. A Sanofi-Synthélabo, por sua vez, havia sido o resultado da fusão, também em 1999, da Sanofi, uma subsidiária da Total, com a Synthélabo, uma subsidiária da L'Oréal (IMS Health, 2011; Gadelha et al., 2007).

\section{Principais Tendências Internacionais no Investimento}

o panorama do setor farmacêutico aqui apresentado encontra-se condicionado por um conjunto de tendências que tende a moldar os padrões de investimento das empresas deste setor em um horizonte de médio prazo. Tais tendências contemplam:

- Mudanças associadas aos vetores de crescimento do mercado global de produtos farmacêuticos.

- Declínio na produtividade das atividades de P\&D: redução no ritmo de registro de novos produtos com características inovadoras.

- Aumento nas pressões competitivas enfrentadas pelos grandes laboratórios farmacêuticos decorrentes da concentração no vencimento de patentes de blockbusters.

- Crescente competição dos medicamentos genéricos: intensificação no processo de fusões e aquisições entre empresas produtoras de medicamentos genéricos.

- Mudanças no marco regulatório associadas às pressões crescentes de consumidores.

No que se refere aos novos vetores de crescimento dessa indústria, não obstante a maior participação absoluta da América do Norte no mercado farmacêutico mundial, no decorrer dos últimos anos o mercado latino-americano e demais mercados emergentes apresentaram taxas de crescimento muito superiores àquelas verificadas nos mercados da América do Norte e Europa. Entre as razões desse crescimento, salientem-se o comportamento das demandas internas, a ampliação dos sistemas nacionais de saúde, o crescimento das exportações no âmbito dos acordos bilaterais de comércio exterior e a ampliação do mercado de medicamentos genéricos (IMS Health, 2011). Adicionalmente, as mudanças no foco da indústria farmacêutica global em direção 
aos mercados emergentes refletem uma combinação de duas outras tendências: o cenário de crescente expiração de patentes e a gradativa redução na produtividade das atividades de $P \& D$ na indústria.

Em 2010, o consumo global de medicamentos atingiu um montante de US\$ 856 bilhões. Nesse período a participação do mercado americano foi de $36 \%$ do gasto total, enquanto que os cinco maiores mercados da União Europeia (EU5) respondiam por $17 \%$ dos gastos totais. Até 2015 estima-se que esse consumo deva atingir um montante entre US\$ 1.065 e 1.095 bilhão, sendo que a participação americana deverá se reduzir para $31 \%$ do consumo global de medicamentos, ao passo que a participação da União Europeia (UE) deverá passar para cerca de 13\% desse total. Os chamados pharmerging markets, que responderam por $18 \%$ do consumo total em 2010, deverão ultrapassar a participação da EU5, chegando a responder por $28 \%$ dos gastos mundiais com medicamentos até 2015. No caso do Japão, demais países da UE e Canadá, a participação nos gastos globais com medicamentos permanece estável, conforme ilustram os Gráficos 8.

Gráficos 8 - Participação nos gastos globais em medicamentos - 2010 e 2015
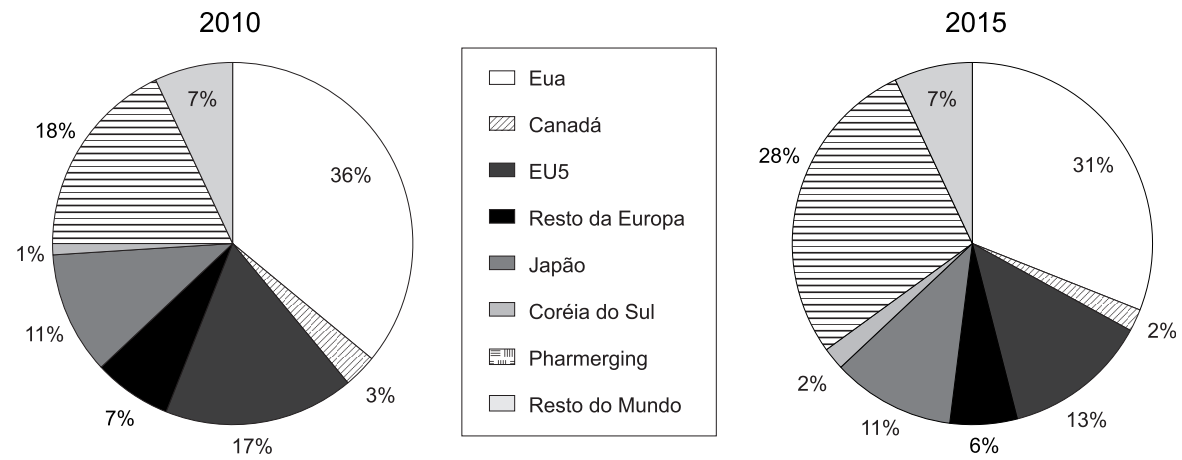

Fonte: IMS Market Prognosis, abr. 2011.

Como resultado do padrão de competição vigente neste setor, as grandes empresas farmacêuticas e de biotecnologia destinam entre $15 \%$ e $20 \%$ das receitas de vendas para as atividades de $P \& D$. Em termos globais o investimento em $P \& D$ no setor farmacêutico supera, inclusive, o de outros setores intensivos em P\&D, tais como o de bens de capital, o automobilístico e o de informática. Em 2009, o setor farmacêutico respondia por cerca de um quinto dos investimentos totais em $P \& D$ feitos pelas mil empresas líderes globais. No mesmo período, das 25 empresas que mais investiram em atividades de P\&D no mundo, oito pertenciam ao setor farmacêutico (R\&D Scoreboard, 2010; Vargas et al., 2010).

Tal padrão de esforço inovativo se reflete também no montante de investimentos necessários para o desenvolvimento de um novo medicamento. De acordo com 
estimativas da indústria americana divulgadas pela Pharmaceutical Research and Manufacturers of America (PhRMA), o processo de desenvolvimento de um novo medicamento envolve um horizonte de 10 a 15 anos e um dispêndio superior a US\$ 1 bilhão (PhRMA, 2011). Por outro lado, o impacto terapêutico de muitas inovações é questionável e ainda persiste grande controvérsia quanto ao que é classificado pela indústria como gasto com $P \& D$ e como gasto com marketing: no processo competitivo assume-se como objetivo maior o lançamento de novos produtos, que envolve atividades tanto de uma quanto de outro. Estima-se que para as grandes empresas da indústria, as big pharma, os gastos com marketing representem o dobro dos gastos alocados em P\&D (Parexel's, 2005).

Entretanto, apesar do investimento crescente no desenvolvimento de novos medicamentos por parte da indústria farmacêutica mundial, observa-se uma redução no ritmo de descoberta e comercialização de Novas Entidades Químicas (NCEs) e Biotecnológicas (NBEs). Por um lado, no caso da indústria farmacêutica americana, o custo estimado para o desenvolvimento de um novo medicamento era de US\$ 138 milhões em 1975, tendo aumentado para US\$ 318 milhões em 1987, US\$ 802 milhões em 2001 e US\$ 1.3 bilhão em 2005 (PhRMA, 2011). Por outro lado, conforme enfatizam Trusheim, Aitkeny e Berndtz (2010), desde meados da década de 1980 o número de novas entidades químicas e biotecnológicas que chegam ao estágio de testes clínicos tem apresentado franco decréscimo. 0 Gráfico 9 ilustra a evolução do número de Novas Entidades Químicas (NMEs) aprovadas por ano e o número de NBEs aprovadas por ano pelo Centro para Avaliação e Pesquisa de Drogas (CDER), órgão vinculado à Food and Drug Administration (FDA) nos EUA. De acordo com os dados apresentados no gráfico, entre 1998 e 2003 o lançamento conjunto de NMEs e NBEs foi, em média, de 34 por ano. Porém, no período subsequente, entre 2004 e 2008, a média anual de lançamento de novas entidades caiu para 21, o que representa uma queda de 37\% em relação ao período anterior (Trusheim, Aitkeny\& Berndtz, 2010).

Adicionalmente, sem entrar na polêmica relativa à natureza do investimento em pesquisa por parte das big pharma, ${ }^{7}$ cabe destacar a importância da base de pesquisa pública para a inovação, a crescente articulação do sistema de C\&T com o setor produtivo e a existência de nichos para as empresas de menor porte para que seja possível adotar estratégias de inovação incrementais (Gadelha et al., 2007; Vargas et al., 2010).

$\mathrm{Na}$ articulação da dinâmica de inovação com a sociedade, pode-se afirmar que o círculo virtuoso entre gasto em P\&D e marketing, inovação, lucratividade e

\footnotetext{
${ }^{7}$ Segundo Angell (2007), P\&D é uma parte relativamente pequena dos orçamentos das empresas farmacêuticas, comparativamente às despesas com marketing e administração. Ao relacionar o número de medicamentos que entraram no mercado em 2002 nos EUA com o que a indústria alega ter gasto em $P \& D$, a autora sugere que o valor efetivamente gasto em P\&D pela indústria depois dos impostos (as despesas de $P \& D$ são totalmente dedutíveis) se situaria em cerca de US\$ 175 milhões para cada medicamento.
} 
crescimento tem uma dimensão perversa em que a lógica de mercado se descola das necessidades de saúde, principalmente daqueles países e populações com menor poder de compra. Esse processo está na raiz dos baixos investimentos para o desenvolvimento de medicamentos destinados a doenças negligenciadas, como malária, lepra, leptospirose, esquistossomose, tuberculose, dengue e leishmaniose, que acometem principalmente os países e regiões menos desenvolvidos. A assimetria na distribuição da base de inovação mundial traz como consequência o acirramento da desigualdade nas condições de saúde em termos internacionais.

Gráfico 9 - Número de novas entidades químicas e biotecnológicas aprovadas. EUA - 1998-2008

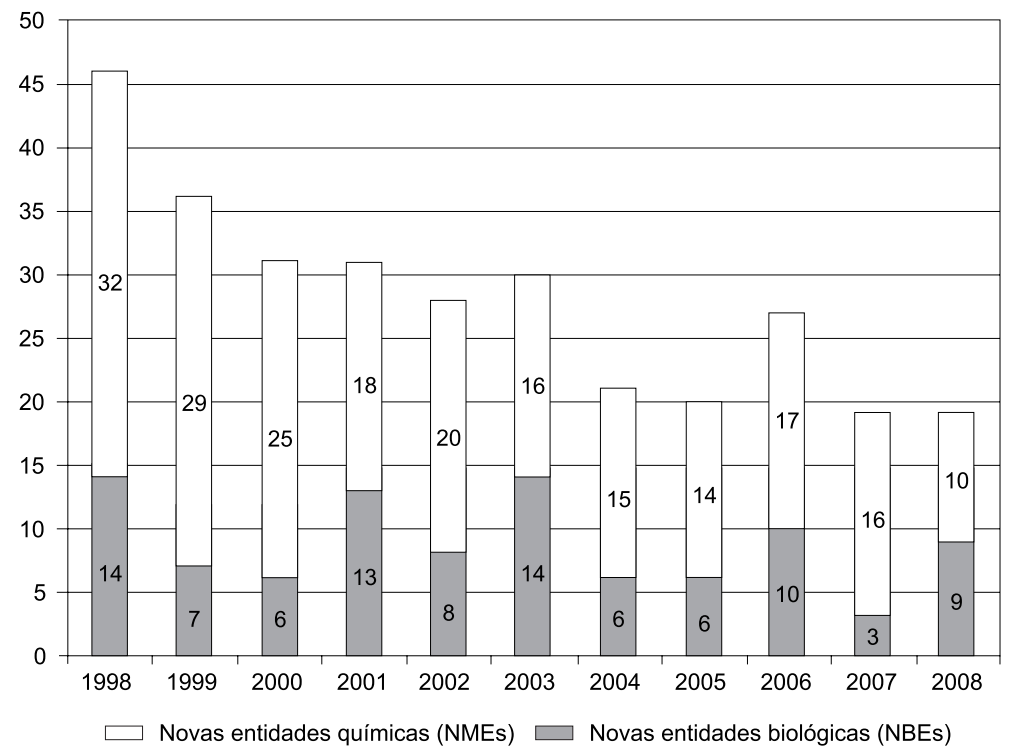

Fonte: PhRMA, 2011.

Uma das alternativas que têm sido adotadas pelas grandes empresas farmacêuticas globais para ampliar a produtividade das suas as atividades de P\&D está relacionada ao processo de externalização de uma parte dessas atividades. Entretanto, ainda que tal estratégia tenha propiciado uma ampliação na participação de economias emergentes no esforço global de $P \& D$ da indústria farmacêutica internacional, verifica-se que tal externalização se concentra em atividades de maior custo e menor densidade de conhecimentos (Vargas et al., 2010).

Nesse contexto cabe ressaltar que, em virtude da intensidade de conhecimentos científicos e tecnológicos que a indústria apresenta, as condições locais de infraestrutura de $P \& D$ são determinantes para a estratégia de configuração global das empresas líderes. As atividades de maior intensidade tecnológica associadas ao processo de $P \& D$ e à produção de princípios ativos tendem a se concentrar nos países desenvol- 
vidos. Ficam para as filiais dos países menos desenvolvidos a produção (formulação) de medicamentos, nos casos justificados pelo tamanho e dinamismo do mercado (a exemplo do Brasil), e atividades tecnológicas mais restritas (a exemplo da aplicação de testes clínicos com metodologias desenvolvidas externamente ou da busca de conhecimentos fortemente localizados, como os provenientes da biodiversidade). Essas estratégias trazem como consequência uma disseminação restringida das atividades que incorporam maior valor agregado e mão de obra mais qualificada, com impacto negativo para a estruturação do sistema de inovação em saúde nesse grupo de países (Gadelha et al., 2007)

Além da redução da produtividade das atividades de P\&D, é importante destacar o viés estrutural da assimetria observada em seus gastos globais. A Tabela 12 apresenta dados da Associação da Indústria Farmacêutica Americana referentes aos gastos de empresas farmacêuticas americanas por região geográfica: a despeito da presença marcante de empresas americanas no mercado brasileiro, que representa atualmente cerca de $2 \%$ do mercado mundial, o Brasil responde por apenas $0,2 \%$ dos gastos em $\mathrm{P} \& D$ dessas empresas (Gadelha et al., 2009).

Tabela 12 -P\&D por região geográfica, no setor farmacêutico para empresas-membros da Pharmaceutical Research and Manufacturers of America (PhRMA) - 2009 (em US\$ milhões)

\begin{tabular}{l|c|c}
\hline ÁREA GEOGRÁFICA & US\$ MILHÕES & DIVISÃ0 (\%) \\
\hline África & 43.1 & 0,1 \\
\hline América & & \\
\hline Estados Unidos & 35.356 .0 & 76,1 \\
\hline Canadá & 444.4 & 1,0 \\
\hline México & 70.9 & 0,2 \\
\hline Brasil & 100.9 & 0,2 \\
\hline Argentina & 24.4 & 0,1 \\
\hline Outros países da América Latina \& Caribe & 218.9 & 0,4 \\
\hline Ásia-Pać́fico & & 1,5 \\
\hline Japão & 676.2 & 0,3 \\
\hline China & 124.4 & 0,3 \\
\hline Índia & 125.1 & 0,8 \\
\hline Outros países Ásia-Pacífico & 395.5 & 0,4 \\
\hline Austrália \& Nova Zelândia & 181.7 & \\
\hline
\end{tabular}


Tabela 12 -P\&D por região geográfica, no setor farmacêutico para empresas-membros da Pharmaceutical Research and Manufacturers of America (PhRMA) - 2009 (em US\$ milhões) ( continuação )

\begin{tabular}{l|c|c}
\hline ÁREA GEOGRÁFICA & US\$ MILHÕES & DIVISÃO (\%) \\
\hline Europa & 365.1 & 0,8 \\
\hline França & 583.2 & 1,3 \\
\hline Alemanha & 210.5 & 0,5 \\
\hline Itália & 223.6 & 0,5 \\
\hline Espanha & 1.937 .4 & 4,2 \\
\hline Reino Unido & 4.315 .6 & 9,3 \\
\hline Outros países do Leste Europeu & 763.4 & 1,7 \\
\hline Leste e Europa Central & 159.6 & 0,3 \\
\hline Rússia & 120.7 & 0,3 \\
\hline Oriente Médio & 1.1 & 0,0 \\
\hline Outros & &
\end{tabular}

Fonte: PhRMA, 2011.

A elevada assimetria nos gastos globais em $P \& D$ na indústria farmacêutica representa um dos grandes desafios para o desenvolvimento do CEIS no Brasil, e particularmente para a indústria farmacêutica nacional, na medida em que tende a ampliar o hiato tecnológico entre o setor farmacêutico brasileiro e a indústria farmacêutica global.

Com relação à tendência relativa ao crescente vencimento de patentes, esse processo teve início em 2001 com a expiração da patente do Prozac da Eli Lilly, antidepressivo de enorme sucesso, e do Prisolec da Astra Zeneca, que, no seu apogeu, gerou um valor de US\$ 6 bilhões ao ano. A patente do Claritin, medicamento que era responsável por um terço do faturamento da Schering-Plough, expirou em 2002 (Angell, 2007 apud Gadelha et al., 2007).

o Quadro 1 destaca os medicamentos cujas patentes expirarão entre os anos de 2011 e 2015 nos principais mercados da indústria farmacêutica.

Assim, além da redução na produtividade das atividades de $P \& D$ dos grandes laboratórios farmacêuticos que se configura como uma tendência da última década, verifica-se um aumento significativo das pressões competitivas sobre as principais empresas do setor, decorrente do vencimento de várias patentes de blockbusters. Neste mesmo quadro de referência, destaca-se o crescimento do mercado dos medicamentos genéricos, que tem representado uma janela de oportunidade, mas também um importante desafio para a indústria farmacêutica brasileira. 
Quadro 1 - Principais patentes a expirar por país e por ano - 2011-2015

\begin{tabular}{|c|c|c|c|c|c|}
\hline ANO DE EXPIRAÇÃO & EUA & JAPÃ0 & REINO UNIDO & FRANÇA & ALEMANHA \\
\hline 2011 & $\begin{array}{l}\text { Lipitor } \\
\text { Advair } \\
\text { iskus } \\
\text { Zyprexa } \\
\text { Levaquin } \\
\text { Xalatan } \\
\text { Femara }\end{array}$ & Actos & \begin{tabular}{|l} 
Lipitor \\
Zyprexa \\
Clexane \\
Xalatan \\
Femara
\end{tabular} & $\begin{array}{l}\text { Zyprexa } \\
\text { Xalatan } \\
\text { Femara }\end{array}$ & $\begin{array}{l}\text { Clexane } \\
\text { Zyprexa } \\
\text { Xalatan } \\
\text { Femara }\end{array}$ \\
\hline 2012 & \begin{tabular}{|l|} 
Plavix \\
Seroquel \\
Singulair \\
Actos \\
Lexapro \\
Diovan
\end{tabular} & Seroquel & $\begin{array}{l}\text { Seroquel } \\
\text { Singulair }\end{array}$ & Singulair & Seroquel \\
\hline 2013 & \begin{tabular}{|l|} 
Oxycontin \\
Aciphex \\
Zometa \\
Xeloda \\
\end{tabular} & $\begin{array}{l}\text { Aricept } \\
\text { Diovan } \\
\text { Plavix }\end{array}$ & $\begin{array}{l}\text { Seretide } \\
\text { Xeloda }\end{array}$ & $\begin{array}{l}\text { Seretide } \\
\text { Xeloda }\end{array}$ & Xeloda \\
\hline 2014 & \begin{tabular}{|l|} 
Nexium \\
Cymbalta \\
Copaxone \\
Celebrex \\
\end{tabular} & Abilify & $\begin{array}{l}\text { Abilify } \\
\text { Celebrex }\end{array}$ & \begin{tabular}{|l|} 
Abilify \\
Celebrex
\end{tabular} & $\begin{array}{l}\text { Abilify } \\
\text { Celebrex }\end{array}$ \\
\hline 2015 & \begin{tabular}{|l|} 
Abilify \\
Gleevec \\
Namenda
\end{tabular} & $\begin{array}{l}\text { Alimta } \\
\text { Spiriva }\end{array}$ & $\begin{array}{l}\text { Spiriva } \\
\text { Alimta }\end{array}$ & $\begin{array}{l}\text { Alimta } \\
\text { Spiriva }\end{array}$ & $\begin{array}{l}\text { Spiriva } \\
\text { Alimta }\end{array}$ \\
\hline
\end{tabular}

Fonte: PhRMA, 2011; Pharmexec.com, 2010.

De acordo com estimativas recentes (IMS Health, 2011), o mercado mundial de genéricos cresce a uma taxa aproximada de $17 \%$ ao ano e movimentará cerca de US\$ 120 bilhões em 2012. No mercado mundial os EUA se destacam com vendas de genéricos da ordem de US $\$ 22$ bilhões, correspondentes a cerca de $60 \%$ das prescrições (Progenéricos, 2012). A Tabela 13 mostra a participação relativa dos medicamentos genéricos em diferentes países nos mercados desenvolvidos e o crescimento estimado desses mercados até 2015.

Tabela 13 - Participação dos medicamentos genéricos no mercado farmacêutico. Países selecionados -2010 e 2015

\begin{tabular}{|c|c|c|}
\hline PAÍS & $\begin{array}{l}\text { PARTICIPACCÃO \% DOS GENÉRICOS NOS GASTOS } \\
\text { FARMACÊUTICOS EM } 2010\end{array}$ & CRESCIMENTO ESTIMADO ATÉ 2015 (EM \%) \\
\hline Canadá & 24,2 & $27-28$ \\
\hline França & 15,3 & $21-22$ \\
\hline Alemanha & 16,2 & $21-22$ \\
\hline
\end{tabular}


Tabela 13 - Participação dos medicamentos genéricos no mercado farmacêutico. Países selecionados - 2010 e 2015 (continuação)

\begin{tabular}{l|c|c}
\hline PAís & $\begin{array}{c}\text { PARTICIPAÇÃ0 \% DOS GENÉRICOS NOS GASTOS } \\
\text { FARMACÊUTICOS EM 2010 }\end{array}$ & \begin{tabular}{c} 
CRESCIMENTO ESTIMADO ATÉ 2015 (EM \%) \\
\hline Itália
\end{tabular} 11,9 \\
\hline Japão & 5,0 & $8-9$ \\
\hline Coreia do Sul & 31,7 & $34-35$ \\
\hline Espanha & 12,8 & $15-16$ \\
\hline Reino Unido & 21,3 & $27-28$ \\
\hline Estados Unidos & 13,4 & $21-22$ \\
\hline
\end{tabular}

Fonte: IMS Health, 2011.

O aumento das pressões competitivas no mercado de medicamentos genéricos tem levado à intensificação do número de fusões e aquisições entre as empresas que nele atuam, o que reflete uma reação das líderes do setor às oportunidades econômicas deste segmento. Dentre as operações recentes que ilustram essa tendência de consolidação de empresas no segmento de genéricos destacam-se, por exemplo: a oferta de US\$ 7 bilhões feita pela israelense Teva - maior fabricante mundial de medicamentos genéricos - para aquisição da concorrente americana Barr; a compra da Ranbaxy - maior fabricante de medicamentos genéricos da Índia - por US\$ 4.6 bilhões pela fabricante japonesa Daiichi Sankyo; a joint venture entre a britânica GlaxoSmithKline e a Aspen da África do Sul. Tal movimento de consolidação tem origem, em grande parte, na necessidade de ganhos de escala que vem sendo imposta pelas crescentes pressões competitivas nesse mercado (The Economist, 2008).

Por fim, crescentes pressões tanto dos consumidores em geral como de órgãos públicos e privados em relação ao preço e ao acesso aos medicamentos estão colocadas na agenda regulatória do subsistema. As mudanças no ambiente regulatório são inúmeras. Envolvem crescente pressão pelo controle de gastos com a saúde, públicos e privados, e intensificação das restrições no âmbito da legislação de regulação sanitária em saúde com crescentes requerimentos de análise para incorporação tecnológica - exigem-se, cada vez mais, protocolos clínicos que atestem a superioridade de medicamentos inovadores de alto valor. No campo da propriedade intelectual, observa-se todo um movimento internacional desde a rodada de Doha da OMC, em que a questão da propriedade intelectual entrou na agenda da saúde pública, acompanhada de um crescente questionamento que envolve desde o conteúdo efetivo de inovação e dos ganhos terapêuticos dos novos produtos até a questão ética das populações, países e regiões excluídos por motivos econômicos do acesso a novos medicamentos que têm efeitos terapêuticos importantes, a exemplo dos que integram o coquetel para o tratamento da Aids. 
Tais fatores são decisivos nas estratégias de investimento no subsistema e tensionam fortemente o padrão de competição setorial em sua interação com os outros subsistemas produtivos do CEIS, particularmente no tocante aos serviços de saúde. É nesse âmbito da interação no interior do sistema produtivo da saúde que tem ocorrido grande parte da mudança no padrão regulatório e do debate sobre o acesso diante da apropriação privada e do preço e lucratividade com medicamentos e outros produtos de base química e biotecnológica.

Da mesma forma, tais fatores apontam para um realinhamento das estratégias corporativas por parte das grandes empresas do setor. Estas têm se beneficiado das oportunidades potenciais nos mercados emergentes; de novas estratégias de negócios com foco em planejamento estratégico; de ganhos de produtividade, sobretudo na $P \& D$; de estratégias de outsourcing em países com menores custos de mão de obra; do crescente interesse em biotecnologia e da entrada no mercado de medicamentos genéricos. Além disso, observa-se um movimento das atividades de $P \& D$ no sentido da focalização da pesquisa em medicamentos para grupos específicos, em contraposição às estratégias excessivamente centradas nos blockbusters (The Economist, 2007; Parexel's, 2007).

Nesse contexto, além das estratégias defensivas para estender direitos de propriedade intelectual com diversas práticas conhecidas como evergreening (e geração de famílias de patentes incrementais com baixa agregação de conhecimento e de inovação) e da tentativa de restringir a entrada de produtos não protegidos por patentes nos seus mercados, as grandes empresas farmacêuticas terão de fazer crescente uso de novas tecnologias, visando a aprofundar o conhecimento e compreensão das doenças, reduzir os custos de P\&D e aumentar a produtividade de seus laboratórios. Ao mesmo tempo, deverão adotar uma visão estratégica mais sistêmica, pautada na cooperação e no entendimento da dinâmica da indústria, que envolve demandas dos pacientes, pagadores, médicos e do próprio sistema político e regulatório (PWC, 2007; Shetty, 2007).

\section{TENDÊNCIAS DO INVESTIMENTO NO BRASIL}

Nesta seção é apresentado um panorama sobre a evolução recente da estrutura industrial e a dinâmica competitiva do subsistema a partir de sua indústria principal, setor farmacêutico nacional, tendo em vista os principais gargalos e oportunidades que se colocam para a expansão dos investimentos no Brasil. E são analisadas algumas das especificidades que marcam o atual padrão de competição nos segmentos de vacinas, hemoderivados e reagentes.

\section{Panorama Nacional: aspectos gerais}

A organização da cadeia produtiva farmacêutica no Brasil envolve um extenso conjunto de empresas e atividades que tem início ainda na indústria de química e particularmente no segmento ligado à produção de insumos farmacêuticos (IFAs, ingredientes farmacêuticos ativos), passando pela importação, fabricação, distribuição e comercialização de medicamentos através de diferentes canais. Além dos fornecedores diretos e indiretos ligados à indústria química e farmoquímica, estima-se que a indústria 
farmacêutica brasileira congregue cerca de seiscentas empresas entre laboratórios, importadores e distribuidores. Entretanto, em termos da sua estrutura produtiva, o setor farmacêutico no Brasil apresenta elevada concentração na região Sudeste.

A Tabela 14 ilustra os padrões de regionalização das atividades de produção de fármacos e medicamentos com base dos dados da Pesquisa Industrial Anual (PIA/IBGE) de 2012. Como pode ser observado na tabela, o estado de São Paulo concentrava, em 2009, 42\% dos estabelecimentos, 53\% do pessoal ocupado, 68\% da Receita Líquida de Vendas (RLV) e 70\% do Valor da Transformação Industrial (VTI) do setor farmacêutico. Juntos, três estados da região Sudeste (São Paulo, Rio de Janeiro e Minas Gerais) concentravam quase $90 \%$ do VTI do setor no país. Fora do eixo Sul-Sudeste destaca-se a participação relativa de Goiás, com cerca de $9 \%$ do emprego e quase $4 \%$ do VTI na produção farmacêutica, que reflete a trajetória relativamente recente de especialização desse estado em atividades ligadas ao setor farmacêutico.

Tabela 14 - Distribuição das atividades do setor farmacêutico nos estados brasileiros segundo variáveis selecionadas da PIA/IBGE - 2009

\begin{tabular}{|c|c|c|c|c|c|c|c|c|c|}
\hline & $\begin{array}{l}\text { UNIDADES } \\
\text { LOCAIS }\end{array}$ & $\%$ UL & $\begin{array}{l}\text { P0 EM } \\
31 / 12\end{array}$ & $\%$ PO & $\begin{array}{c}\text { TOTAL DE RLV } \\
\text { (MIL REAIS) }\end{array}$ & $\%$ RLV & $\begin{array}{c}\text { VTI } \\
\text { (MIL REAIS) }\end{array}$ & $\%$ VTI & $\begin{array}{l}\text { \% VTI } \\
\text { ACUM. }\end{array}$ \\
\hline São Paulo & 332 & $42,2 \%$ & 49.524 & $52,7 \%$ & 22.224 .830 & $67,6 \%$ & 12.963 .167 & $70,0 \%$ & $70,0 \%$ \\
\hline Rio de Janeiro & 108 & $13,7 \%$ & 9.925 & $10,6 \%$ & 5.378 .800 & $16,4 \%$ & 2.529 .826 & $13,7 \%$ & $83,6 \%$ \\
\hline Minas Gerais & 79 & $10,0 \%$ & 8.452 & $9,0 \%$ & 1.318 .797 & $4,0 \%$ & 953.348 & $5,1 \%$ & $88,8 \%$ \\
\hline Goiás & 49 & $6,2 \%$ & 8.747 & $9,3 \%$ & 1.297.471 & $3,9 \%$ & 728.105 & $3,9 \%$ & $92,7 \%$ \\
\hline Paraná & 47 & $6,0 \%$ & 4.437 & $4,7 \%$ & 659.380 & $2,0 \%$ & 362.038 & $2,0 \%$ & $94,7 \%$ \\
\hline Rio Grande do Sul & 54 & $6,9 \%$ & 2.563 & $2,7 \%$ & 642.243 & $2,0 \%$ & 261.463 & $1,4 \%$ & $96,1 \%$ \\
\hline Ceará & 16 & $2,0 \%$ & 2.893 & $3,1 \%$ & 263.909 & $0,8 \%$ & 226.836 & $1,2 \%$ & $97,3 \%$ \\
\hline Santa Catarina & 23 & $2,9 \%$ & 3.249 & $3,5 \%$ & 489.797 & $1,5 \%$ & 210.095 & $1,1 \%$ & $98,4 \%$ \\
\hline Distrito Federal & 8 & $1,0 \%$ & 1.014 & $1,1 \%$ & 215.573 & $0,7 \%$ & 158.435 & $0,9 \%$ & $99,3 \%$ \\
\hline Pernambuco & 27 & $3,4 \%$ & 1.453 & $1,5 \%$ & 121.314 & $0,4 \%$ & 47.144 & $0,3 \%$ & $99,5 \%$ \\
\hline Amazonas & 3 & $0,4 \%$ & 101 & $0,1 \%$ & 31.605 & $0,1 \%$ & 25.981 & $0,1 \%$ & $99,7 \%$ \\
\hline Bahia & 10 & $1,3 \%$ & 522 & $0,6 \%$ & 41.655 & $0,1 \%$ & 20.336 & $0,1 \%$ & $99,8 \%$ \\
\hline Piauí & 6 & $0,8 \%$ & 387 & $0,4 \%$ & 28.645 & $0,1 \%$ & 13.417 & $0,1 \%$ & $99,9 \%$ \\
\hline Mato Grosso do Sul & 3 & $0,4 \%$ & 120 & $0,1 \%$ & 8.315 & $0,0 \%$ & 4.501 & $0,0 \%$ & $99,9 \%$ \\
\hline Pará & 5 & $0,6 \%$ & 59 & $0,1 \%$ & 1.435 & $0,0 \%$ & 941 & $0,0 \%$ & $99,9 \%$ \\
\hline Brasil & 787 & & 93.920 & & 32.859 .088 & & 18.526 .798 & & \\
\hline
\end{tabular}

P0 - Pessoal Ocupado; RLV - Receita Líquida de Vendas; UL - Unidades Locais; VTI - Valor da Transformação Industrial. Fonte: PIA/IBGE, 2012b. Elaboração própria a partir dos dados obtidos na fonte. 
Em 2010, o mercado farmacêutico nacional ocupava a oitava posição no ranking internacional de vendas globais da indústria farmacêutica e contava com um faturamento da ordem de $\mathrm{R} \$ 36,2$ bilhões. Apesar do claro predomínio das grandes empresas multinacionais no mercado nacional, em diferentes segmentos e classes terapêuticas, verificou-se um aumento considerável na participação de empresas nacionais no mercado ao longo da década de 2000 . Assim, estima-se que a participação das empresas de capital nacional no total do mercado farmacêutico brasileiro tenha aumentado de $32,5 \%$ para mais de $50 \%$ entre 2003 e 2010. Em 2010, quatro laboratórios farmacêuticos nacionais - Aché, EMS, Eurofarma e Hypermarcas - figuravam entre as dez maiores empresas do setor no país, enquanto que no passado essa presença se limitava a uma ou duas empresas (Vargas et al., 2010; Reis, Landin \& Pieroni, 2011).

A Tabela 15 apresenta a evolução das vendas nominais em reais, em dólares e em unidades vendidas da indústria farmacêutica no Brasil entre 2003 e 2011.

Tabela 15 - Mercado farmacêutico, vendas nominais em R\$, US\$ e unidades. Brasil - 2003-2011

\begin{tabular}{l|c|c|c|c}
\hline ANO & VENDAS EM R\$* & VENDAS EM US\$* & VENDAS EM UNIDADES & VARIAÇÃ0\% \\
\hline 2003 & 14.780 .035 .430 & 4.852 .551 .683 & 1.219 .059 .330 & - \\
\hline 2004 & 17.254 .159 .949 & 5.903 .242 .169 & 1.332 .962 .885 & $9,34 \%$ \\
\hline 2005 & 19.227 .311 .353 & 7.953 .595 .364 & 1.374 .337 .043 & $3,10 \%$ \\
\hline 2006 & 21.452 .327 .098 & 9.868 .158 .578 & 1.436 .958 .119 & $4,56 \%$ \\
\hline 2007 & 23.583 .331 .115 & 12.179 .582 .492 & 1.517 .566 .838 & $5,61 \%$ \\
\hline 2008 & 26.398 .308 .322 & 14.648 .704 .823 & 1.632 .054 .560 & $7,54 \%$ \\
\hline 2009 & 30.172 .360 .392 & 15.406 .961 .454 & 1.767 .001 .730 & $8,27 \%$ \\
\hline 2010 & 36.230 .906 .182 & 20.630 .804 .119 & 2.070 .444 .076 & $17,17 \%$ \\
\hline $2011 * *$ & 39.958 .727 .794 & 24.135 .225 .464 & 2.233 .587 .384 & $7,88 \%$ \\
\hline
\end{tabular}

* Preços fábrica (sem desconto com impostos inclusos).

** 12 meses móveis até novembro de 2011.

Fonte: Sindusfarma, 2012.

$\mathrm{Na}$ franja do mercado, situam-se ainda os laboratórios farmacêuticos oficiais e as pequenas empresas de base biotecnológica, formadas a partir de spin-offs acadêmicos. Não obstante, esses dois grupos de agentes têm capacidade competitiva limitada, seja pela dependência de mercado, seja por práticas gerenciais pouco adequadas ao padrão de competição setorial.

No caso dos laboratórios públicos, destacam-se instituições como a Fundação para o Remédio Popular (Furp) e o Instituto Butantan, em São Paulo, e Bio-Manguinhos e Farmanguinhos, da Fundação Oswaldo Cruz (Fiocruz), no Rio de Janeiro, que estão 
entre os maiores produtores públicos no país e integram a rede pública de produção de medicamentos. O país conta hoje com uma rede de 21 laboratórios públicos espalhados por todo o território nacional, reunidos na Associação dos Laboratórios Farmacêuticos Oficiais (Alfob). Desse total, 16 estão em pleno funcionamento. O mais novo laboratório é a Bahiafarma, que foi reativada em 2011 pelo governo do estado da Bahia com auxílio da Secretaria de Ciência, Tecnologia e Insumos Estratégicos do Ministério da Saúde (SCTIE/MS). Além de sua ampla abrangência nacional, essa rede de laboratórios oficiais responde hoje por cerca de $3 \%$ do valor da produção nacional de medicamentos e por cerca de $10 \%$ do volume total produzido (Bastos, 2005). No caso da produção de vacinas, os laboratórios oficiais respondem por aproximadamente $80 \%$ da demanda doméstica. Os laboratórios oficiais desempenham papel destacado na Política Nacional de Saúde (PNS), seja na produção de medicamentos para o Sistema Único de Saúde (SUS), no suporte à regulação ou no processo de capacitação tecnológica.

O aumento da participação de laboratórios nacionais no mercado farmacêutico brasileiro esteve particularmente associado à consolidação do segmento de medicamentos genéricos no país. ${ }^{8}$ Os medicamentos genéricos respondem por 20,6\% das vendas, em unidades, no mercado farmacêutico brasileiro, percentual ligeiramente inferior ao verificado em países como Reino Unido, Canadá e Coreia do Sul, onde o mercado de medicamentos genéricos já se encontra consolidado (IMS Health, 2011).

De acordo com informações da Associação Brasileira das Indústrias de Medicamentos Genéricos - Progenéricos, há mais de dez anos presente no mercado brasileiro, a indústria de genéricos já investiu cerca de US\$ 170 milhões na construção e modernização de plantas industriais e tem atraído investimentos dos grandes laboratórios multinacionais em função do dinamismo do mercado brasileiro. No primeiro trimestre de 2011 já havia mais de 3.100 medicamentos genéricos registrados no país para o tratamento de várias doenças graves como diabetes, glaucoma, hipertensão, câncer de mama, mal de Parkinson e Aids.

A trajetória recente de aumento da participação de empresas farmacêuticas brasileiras no mercado nacional, por sua vez, tem sido acompanhada por intenso movimento de fusões e aquisições. Tal movimento reflete tanto uma estratégia de consolidação patrimonial de empresas nacionais, estimulada pelo aumento das pressões competitivas no mercado de genéricos, como um realinhamento das estra-

\footnotetext{
${ }^{8}$ Em 1999, a Lei 9.787 instituiu o medicamento genérico no país, de acordo com as normas internacionais adotadas por países da União Europeia, EUA, Canadá, além da Organização Mundial da Saúde (OMS). Essa lei foi regulamentada pela Resolução 391, do mesmo ano, e apresentava todos os critérios sobre produção, ensaios de bioequivalência, de biodisponibilidade, registro, prescrição e dispensação de medicamentos genéricos. Em janeiro de 2001, foi publicada a Resolução 10, em substituição à Resolução 391. O objetivo foi dar maior agilidade ao processo de registro de medicamentos genéricos e melhorar o fluxo das análises. A norma agregou informações, revisou pontos da resolução original e preencheu lacunas, como a regularização do registro de genéricos importados (Anvisa, 2008).
} 
tégias corporativas por parte dos grandes laboratórios multinacionais com vista a se beneficiar das oportunidades potenciais nos mercados emergentes. ${ }^{9}$

O Quadro 2 relaciona as aquisições recentes da indústria farmacêutica no Brasil. O laboratório Aché, por exemplo, ao adquirir a Biosintética em 2005 tornou-se líder do mercado. No mesmo ano, a Biolab comprou $80 \%$ da Sintefina, uma empresa farmoquímica nacional, e o Libbs adquiriu as operações da australiana Mayne, importante fabricante de medicamentos oncológicos (Valor Econômico, 2007). Esse movimento de fusões e aquisições foi particularmente intenso em 2009. A Pfizer, por exemplo, chegou a iniciar as negociações com a Neo Química, que acabou sendo adquirida por R $\$ 1,3$ bilhão pela Hypermarcas. O laboratório Medley, uma das principais empresas nacionais do setor, foi adquirido por R\$1,5 bilhão pela Sanofi-Aventis, que, com a aquisição, reforçou sua posição no segmento de genéricos no país. A previsão é de que os investimentos em fusões e aquisições por parte das multinacionais farmacêuticas se ampliem consideravelmente nos próximos anos. Dentre as empresas que anunciaram investimentos em aquisições no mercado brasileiro é possível mencionar a Zambon do Brasil, de capital italiano, que prevê um investimento de $€ 100$ milhões destinados à aquisição de laboratório de médio porte; a Ferring Farmacêutica, de capital suíço, que prevê investir entre US\$50 e 100 milhões em aquisições, ou a dinamarquesa Nycomed, que também planeja reforçar sua posição no mercado brasileiro (Valor Econômico, 2010b).

Quadro 2 - Aquisições realizadas na indústria farmacêutica. Brasil - 2005-2010

\begin{tabular}{|c|l|l|}
\hline ANO & ADQUIRENTE & ADQUIRIDA \\
\hline 2005 & Aché & $\begin{array}{l}\text { Astamedica } \\
\text { Biosintética }\end{array}$ \\
\hline 2005 & Biolab & $\begin{array}{l}\text { Dalmatia } \\
\text { Sintefina }\end{array}$ \\
\hline 2005 & Libbs & Mayne Pharma do Brasil \\
\hline 2006 & AstraZeneca & Cambridge Antibody Technology \\
\hline 2006 & Bayer & Schering \\
\hline 2009 & Sanofi-Aventis & Medley \\
\hline 2009 & Hypermarcas & Neoquímica \\
\hline 2010 & Pfizer & Teuto (aquisição de 40\%) \\
\hline 2010 & Eurofarma & Segmenta \\
\hline
\end{tabular}

Fonte: atualizado a partir de Barbosa, Mendes \& Sennes, 2007.

\footnotetext{
${ }^{9}$ Em âmbito mundial, conforme destacado na seção anterior, o aumento das pressões competitivas no segmento de medicamentos genéricos também tem levado à intensificação do número de fusões e aquisições entre as empresas que atuam neste segmento. Tal movimento de consolidação tem origem, em grande parte, na necessidade de ganhos de escala que vem sendo imposta pelas crescentes pressões competitivas no mercado de medicamentos genéricos.
} 
Destaca-se, portanto, uma mudança estrutural no contexto nacional em termos de capacidade produtiva de medicamentos finais formulados, a qual tem resultado em aumento da participação de empresas nacionais no mercado. Em seu conjunto, entretanto, as empresas nacionais ainda apresentam porte reduzido, em comparação com os conglomerados multinacionais, e inserção ainda modesta em nichos de produtos de maior valor agregado, particularmente no caso de produtos e processos que envolvem a rota biotecnológica.

\section{Balança Comercial}

Um dos principais reflexos da fragilidade da base produtiva em saúde no âmbito da indústria de base química e biotecnológica no Brasil foi o crescimento acelerado, ao longo da última década, do déficit na balança comercial de fármacos e medicamentos. Apesar do dinamismo recente do mercado farmacêutico brasileiro, verificou-se expansão acelerada das importações de fármacos e medicamentos na última década, a qual resultou em uma situação de desequilíbrio estrutural da balança comercial da indústria de base química e biotecnológica, particularmente nos segmentos mais intensivos em conhecimento da indústria farmacêutica.

Esse déficit estrutural na balança comercial de fármacos e medicamentos reflete o próprio contexto histórico de desenvolvimento da indústria farmacêutica no Brasil. ${ }^{10}$ Conforme destacado por Gadelha (1990), a instalação no país de subsidiárias das grandes empresas do setor no fim da década de 1950 resultou da adequação do espaço econômico nacional à lógica e dinâmica de funcionamento da indústria farmacêutica internacional. Porém, a exemplo do que ocorreu em outros setores da indústria nacional, essa adequação ocorreu de forma truncada e parcial, na medida em que não envolveu a interiorização completa da estrutura produtiva e tecnológica vigente nos países desenvolvidos. Em virtude quer da inexistência de fatores endógenos como, por exemplo, política industrial setorial e/ou estratégias ativas de empresas nacionais, quer das próprias estratégias das multinacionais, montaram-se estruturas de produção e comercialização centradas na produção de medicamentos, mas não

\footnotetext{
${ }^{10}$ A conformação histórica da indústria farmacêutica no Brasil tem sido abordada em diversos trabalhos recentes (Queiroz \& Gonzáles, 2001; Gadelha et al., 2007; Bastos, 2005; Capanema, 2006, entre outros). Para o escopo deste trabalho, destacam-se as características vigentes até o final do século passado, que envolvem alto dinamismo da produção de medicamentos finais, domínio do mercado pelas empresas líderes do oligopólio mundial e realização restrita das atividades de maior densidade tecnológica, com destaque para a reduzida participação na oferta da produção de ingredientes farmacêuticos ativos (IFAs ou fármacos) e pela quase desprezível realização de atividades de $\mathrm{P} \& \mathrm{D}$, com exceção das realizadas no âmbito dos produtores públicos mais capacitados em biotecnologia - a Fiocruz e o Butantan - no campo das vacinas e reagentes para diagnóstico e de algumas iniciativas privadas para a produção de farmoquímicos que foram abortadas pelas políticas liberais dos anos 90, relacionadas sobretudo ao comércio exterior e à adoção da legislação de propriedade intelectual em 1996, sem que fossem aproveitadas as flexibilidades previstas pelo Trips para os períodos de transição.
} 
ocorreu, salvo raras exceções, um processo de integração para a área de fármacos e muito menos para atividades de P\&D.

Na década de 1970 o Brasil já era o principal mercado latino-americano e o sétimo mercado mundial em um contexto no qual a oferta interna de medicamentos praticamente supria todo o mercado nacional, porém com elevada dependência da importação de insumos farmacêuticos (fármacos e intermediários de síntese). A participação de empresas estrangeiras no mercado nacional nesse período situava-se em torno de $77 \%$ (Gadelha, 1990).

Na década de 1980, em que pese a manutenção do quadro geral da indústria farmacêutica, e mesmo a ampliação da participação de empresas estrangeiras no mercado nacional, que sobe para $85 \%$, verificou-se o surgimento de algumas iniciativas locais voltadas para o aumento da produção local de fármacos: política de compras do Ministério da Saúde (MS), mecanismos de proteção do mercado nacional via restrição às importações, e a própria Lei de Patentes vigente, que viabilizava mecanismos de reprodução de processos tecnológicos na área de fármacos. Como exemplos destacados desse tipo de iniciativa citam-se a Companhia de Desenvolvimento Tecnológico (Codetec), empresa de desenvolvimento de síntese química de fármacos, e a Biobrás, na produção de insulina (Gadelha et al., 2007).

o processo de liberalização comercial, abertura econômica e desregulamentação de mercados na década de 90 do último século levou aquelas iniciativas voltadas para mudanças estruturais da indústria a serem abortadas. Em um cenário de abertura comercial e valorização cambial, a indústria farmacêutica brasileira tornou-se fortemente dependente de importações, privilegiadas em detrimento da produção doméstica. No âmbito das estratégias globais das empresas multinacionais, unidades farmacêuticas foram desativadas e optou-se pela importação da matriz ou de outras subsidiárias.

A liberalização comercial, além de outros fatores macroeconômicos, revelou-se extremamente negativa para a indústria farmacêutica nacional, impactando fortemente a competitividade da produção local nos segmentos de maior densidade tecnológica. Devese destacar, ainda, a reestruturação da produção mundial das grandes multinacionais associada ao intenso processo de conglomeração industrial ao longo da década de 90. Assim, a confluência de um mercado interno que não gerava maiores incentivos à produção local com o processo de reestruturação global da indústria acarretou uma explosão das importações e a rápida deterioração das condições externas do setor (Gadelha, 2002). Nesse aspecto, não obstante o fato de a indústria farmacêutica nacional responder por cerca de $80 \%$ dos medicamentos consumidos no mercado doméstico nesse período, cerca de $82 \%$ dos insumos farmacêuticos utilizados na fabricação desses medicamentos já eram importados. A incapacidade do segmento farmoquímico nacional de atender a uma demanda crescente dos fabricantes de medicamentos acarretou um aumento explosivo na importação de fármacos a partir de 2004.

É importante ressaltar que esse processo não se deu de forma diretamente associada a uma ampliação do hiato tecnológico, uma vez que 83\% dos fármacos 
importados têm patentes anteriores ao ano de 1977 e 47\% as têm desde antes de 1962, não se tratando, portanto, de uma questão associada unicamente ao horizonte das competências tecnológicas das empresas locais. $\mathrm{Na}$ área de medicamentos, há uma parcela expressiva dos itens importados que também é tradicional, não incidindo, para esses produtos, barreiras ligadas à propriedade intelectual (Magalhães et al., 2002; Gadelha et al. 2007). Assim, apesar do dinamismo do mercado farmacêutico brasileiro, o processo de liberalização comercial aliado aos importantes gargalos associados ao desenvolvimento da cadeia produtiva farmacêutica nacional resultou em um considerável desequilíbrio estrutural da balança comercial relativa aos principais segmentos da indústria farmacêutica.

A evolução do déficit na balança comercial para o conjunto de segmentos da indústria de base química e biotecnológica em saúde entre 1996 e 2011 é apresentada no Gráfico 10, no qual se pode observar também que entre 1996 e 2003 o déficit comercial se manteve em um patamar entre US\$ 2 e 3 bilhões. A partir de 2004, entretanto, verifica-se uma expansão significativa do déficit, ocasionada pelo aumento explosivo das importações. Assim, em um período de sete anos, entre 1996 e 2003, as importações apresentaram um crescimento acumulado de cerca de $20 \%$, passando de US\$ 2.52 bilhões em 1996 para cerca de US\$ 3 bilhões em 2003. Por sua vez, no decorrer dos sete anos seguintes, entre 2004 e 2011, esse crescimento foi de $156,6 \%$, resultando em um aumento das importações para um patamar de US\$ 9.41 bilhões. Nesse último período (2004-2011), as exportações também apresentaram uma taxa de crescimento acumulado expressivo (228\%), passando de US\$540 milhões em 2004 para US\$ 1.78 bilhão em 2011, porém se mantiveram em um patamar significativamente menor do que as importações, o que evidencia uma clara assimetria no padrão de inserção internacional do país no âmbito do comércio exterior.

Gráfico 10 - Balança comercial da indústria de base química e biotecnológica em saúde. Brasil 1996-2011

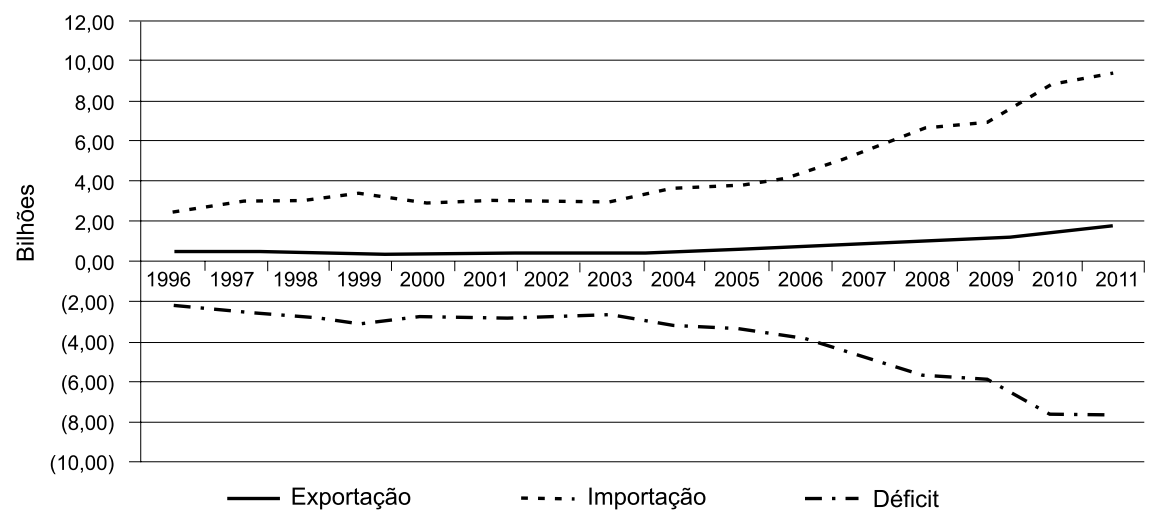

Fonte: elaborado por GIS/Ensp/Fiocruz, 2012, com base em dados do Alice Web (Brasil. Ministério do Desenvolvimento, Indústria e Comércio Exterior, 2012). 
A análise do déficit comercial consolidado para os diferentes segmentos que integram a indústria de base química e biotecnológica no complexo industrial da saúde, em 2011, revela que cerca de dois terços desse déficit (63\%) encontram-se relacionados às importações de fármacos e medicamentos. Assim, nesse mesmo período, do déficit total de US\$ $7.64,34 \%$ ou US\$ 2.6 bilhões foram decorrentes do déficit da importação de medicamentos; $30 \%$ ou US $\$ 2.3$ bilhões da importação de fármacos (insumos farmacêuticos); $22 \%$ ou US\$ 1.7 bilhão da importação de hemoderivados; $7 \%$ ou US\$ 500 milhões decorrentes da importação de vacinas, e os restantes $7 \%$ oriundos da importação de soros e reagentes para diagnóstico. A participação relativa de cada segmento no déficit total é apresentada nos Gráficos 11.

Gráficos 11 - Balanç̧a comercial nos segmentos de base química e biotecnológica do CEIS. Brasil - 2011

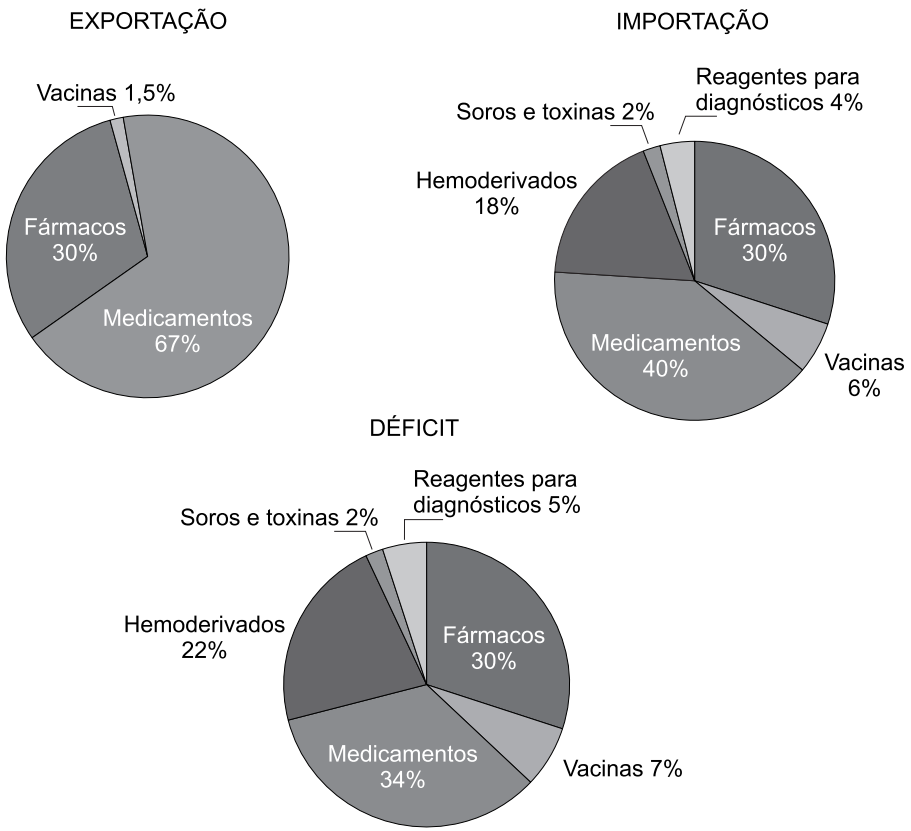

Fonte: GIS/Ensp/Fiocruz, a partir dos dados do Alice Web (Brasil. Ministério do Desenvolvimento, Indústria e Comércio Exterior, 2012).

No caso da balança comercial consolidada de medicamentos, de acordo com dados coletados pelo Grupo de Estudos do Complexo Econômico-Industrial da Saúde (GIS/Ensp/Fiocruz) a partir da base do Alice Web/MDIC, entre 1996 e 2003 o déficit comercial de medicamentos se manteve em um patamar de US\$ 1.1 bilhão, conforme demonstra o Gráfico 12. Entretanto, em 2004 esse déficit experimentou crescimento de $15 \%$ em relação ao ano anterior, mantendo crescimento médio de $12 \%$ ao ano, o que provocou seu aumento explosivo. Como resultado, no ano de 2011 o déficit atinge um montante de US\$ 2.56 bilhões. 
Gráfico 12 - Balança comercial consolidada de medicamentos. Brasil - 1996-2011 (em US\$ bilhões F0B*)

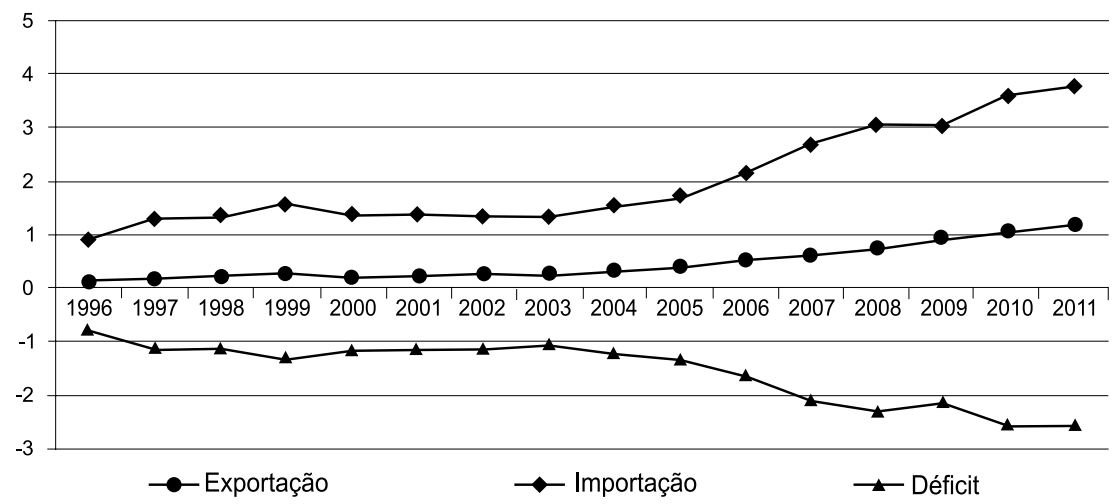

* Free on Board (mercadorias a preço de embarque, exclui o pagamento de fretes, seguros, impostos e taxas de embarque). Fonte: GIS/Ensp/Fiocruz, a partir de dados do Alice Web (Brasil. Ministério do Desenvolvimento, Indústria e Comércio Exterior, 2012).

No tocante às importações de medicamentos, o Brasil é fortemente dependente dos EUA e da UE, cujas empresas definem suas estratégias globais de dispersão geográfica da produção mediante o lançamento de novos produtos desenvolvidos, basicamente, a partir de suas bases em seus países de origem e, crescentemente, de economias emergentes, como é o caso da China e da Índia. Do lado das exportações, destaca-se a forte inserção das exportações brasileiras de medicamentos em países da América Latina. Nesse caso, ressalta-se, novamente, a estratégia das multinacionais que vêm utilizando o Brasil como plataforma de exportação de seus produtos para os países da região (Gadelha et al., 2007; Vargas et al., 2010).

A Tabela 16 apresenta a composição do déficit na balança comercial de medicamentos em 2009 e 2010, tendo em vista a participação dos principais países ou blocos de origem dessas importações. Conforme se pode observar na tabela, em 2010 as importações provenientes da UE e EUA responderam conjuntamente por 82\% do déficit total na balança comercial de medicamentos, ao passo que em 2009 essa participação era de aproximadamente $80 \%$. Nesse mesmo período, a Índia respondeu por cerca de $4 \%$ do déficit e o Japão por menos de 3\% desse total.

Se as importações de medicamentos se mostram fortemente concentradas em poucos blocos e países, as exportações apresentaram maior amplitude em termos de países de destino, apesar da participação expressiva da UE. Adicionalmente, destacase a importância do Mercado Comum do Sul (Mercosul) como destino de quase $15 \%$ das exportações brasileiras de medicamentos e com reduzida participação nas importações totais (aproximadamente 3\%). 
Tabela 16 - Balança comercial de medicamentos. Participação por blocos - 2009 e 2010

\begin{tabular}{|c|c|c|c|c|c|c|}
\hline \multirow{2}{*}{ PAÍS/BLOCO } & \multicolumn{3}{|c|}{2010} & \multicolumn{3}{|c|}{2009} \\
\hline & EXPORTAÇÃO & IMPORTAÇÃO & DÉFICIT & EXPORTAÇÃO & IMPORTAÇÃO & DÉFICIT \\
\hline União Europeia & $29,58 \%$ & $50,40 \%$ & $59,67 \%$ & $24,42 \%$ & $45,74 \%$ & $55,16 \%$ \\
\hline Estados Unidos & $5,57 \%$ & $17,02 \%$ & $22,12 \%$ & $5,01 \%$ & $18,45 \%$ & $24,39 \%$ \\
\hline Resto do mundo & $46,63 \%$ & $24,03 \%$ & $13,97 \%$ & $53,05 \%$ & $27,09 \%$ & $15,62 \%$ \\
\hline Índia & $0,96 \%$ & $3,58 \%$ & $4,74 \%$ & $0,20 \%$ & $3,33 \%$ & $4,71 \%$ \\
\hline Japão & $0,03 \%$ & $0,92 \%$ & $1,32 \%$ & $0,09 \%$ & $1,19 \%$ & $1,67 \%$ \\
\hline China & $2,82 \%$ & $0,86 \%$ & $-0,01 \%$ & $0,76 \%$ & $0,88 \%$ & $0,94 \%$ \\
\hline Mercosul & $14,40 \%$ & $3,18 \%$ & $-1,82 \%$ & $16,48 \%$ & $3,32 \%$ & $-2,50 \%$ \\
\hline
\end{tabular}

Fonte: elaborado por GIS/Ensp/Fiocruz, 2012, a partir de dados do Alice Web (Brasil. Ministério do Desenvolvimento, Indústria e Comércio Exterior, 2012). Valores em US\$ bilhões atualizados pelo IPC-EUA.

A evolução da balança comercial de insumos farmacêuticos no período 1996-2011 indica a mesma tendência de crescimento das importações verificada a partir de 2004 no caso dos medicamentos. O aumento explosivo na importação de fármacos a partir de 2004 esteve particularmente associado à incapacidade das empresas nacionais do segmento farmoquímico para atenderem à demanda crescente dos fabricantes de medicamentos em um contexto de crescimento do mercado farmacêutico brasileiro induzido pela regulamentação dos medicamentos genéricos no país. Assim, entre 2004 e 2011 as importações de insumos farmacêuticos aumentaram de um patamar de US\$ 1.6 bilhão para US\$ 2.8 bilhões, o que representou um crescimento de $77 \% \mathrm{em}$ termos reais no período ou uma taxa de crescimento médio anual de 8,6\% (Gráfico 13).

Gráfico 13 - Balança comercial consolidada de fármacos. Brasil - 1996-2011 (US\$ bilhões FOB*)

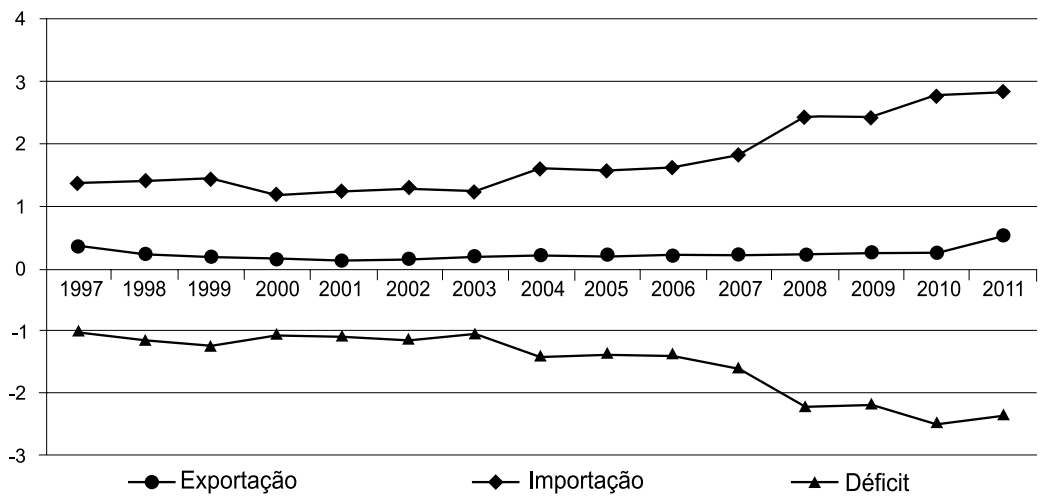

* Free on Board (mercadorias a preço de embarque, exclui o pagamento de fretes, seguros, impostos e taxas de embarque).

Fonte: GIS/Ensp/Fiocruz, a partir de dados do Alice Web (Brasil. Ministério do Desenvolvimento, Indústria e Comércio Exterior, 2012). 
Em termos da distribuição geográfica das importações de fármacos, destacase, além da participação expressiva da UE, a presença da China e da Índia entre os maiores mercados de origem das importações. Em 2010, a UE respondeu por 53\% das importações e por $56 \%$ do déficit, enquanto China e Índia foram responsáveis por, respectivamente, $23 \%$ e $9 \%$ das importações e por $25 \%$ e $10 \%$ do déficit total com a importação de fármacos. Conjuntamente, esses três blocos responderam por mais de $90 \%$ das importações brasileiras neste segmento do complexo produtivo da saúde, conforme ilustrado na Tabela 17.

Tabela 17 - Balança comercial de fármacos, 2009 e 2010, participação por blocos

\begin{tabular}{l|c|c|c|c|c|c}
\hline \multirow{2}{*}{ PAís/BLOCO } & \multicolumn{3}{|c|}{2010} & \multicolumn{3}{c}{2009} \\
\cline { 2 - 7 } & EXPORTAÇÃO & IMPORTAÇÃO & DÉFICIT & EXPORTAÇÃ0 & IMPORTAÇÃO & DÉFICIT \\
\hline União Europeia & $20 \%$ & $53 \%$ & $57 \%$ & $32,80 \%$ & $54 \%$ & $56 \%$ \\
\hline China & $0 \%$ & $23 \%$ & $25 \%$ & $0,24 \%$ & $20 \%$ & $22 \%$ \\
\hline Índia & $1 \%$ & $9 \%$ & $10 \%$ & $0,36 \%$ & $9 \%$ & $11 \%$ \\
\hline Japão & $16 \%$ & $5 \%$ & $4 \%$ & $13,65 \%$ & $9 \%$ & $8 \%$ \\
\hline Estados unidos & $32 \%$ & $6 \%$ & $4 \%$ & $14,92 \%$ & $4 \%$ & $3 \%$ \\
\hline Resto do mundo & $22 \%$ & $3 \%$ & $2 \%$ & $31,04 \%$ & $4 \%$ & $1 \%$ \\
\hline Rússia & $0 \%$ & $0 \%$ & $0 \%$ & $6,60 \%$ & $0 \%$ & $-1 \%$ \\
\hline Mercosul & $9 \%$ & $0 \%$ & $-1 \%$ & $0,39 \%$ & $0 \%$ & $0 \%$ \\
\hline
\end{tabular}

Fonte: elaborado por GIS/Ensp/Fiocruz, 2012, a partir de dados do Alice Web (Brasil. Ministério do Desenvolvimento, Indústria e Comércio Exterior, 2012). Valores em US\$ bilhões atualizados pelo IPC-EUA.

Finalmente, cabe destacar que um dos fatores que mais têm contribuído para o aumento exponencial do déficit na balança de medicamentos e fármacos está associado à importação de produtos de base biotecnológica. Entre 2005 e 2010 as importações de produtos biológicos cresceram, em média, 37\% ao ano. Da mesma forma, oito entre os dez principais medicamentos com maior valor de importação são produzidos por rota biotecnológica (Reis, Landin \& Pieroni, 2011). O peso elevado dos produtos de base biotecnológica no déficit da balança comercial da saúde fica ainda mais evidente quando se analisa a importação de vacinas e hemoderivados. No segmento de vacinas, dentre os cinco principais componentes do déficit destacam-se vacinas gênicas de terceira geração que responderam conjuntamente por cerca de $38 \%$ do déficit na balança comercial do segmento em 2011. No caso dos hemoderivados, chama a atenção o valor expressivo relativo à importação de anticorpos monoclonais, produtos biológicos de segunda geração, tanto por seu peso elevado no déficit comercial de hemoderivados (cerca de 37\%) como por seu elevado valor unitário (cerca de US\$ 16 mil/Kg). A análise 
sobre as especificidades que marcam o atual estágio de desenvolvimento tecnológico desses segmentos no âmbito do CEIS será retomada a seguir.

\section{Base Produtiva: gargalo na produção de IFAs}

Na medida em que os dados agregados da balança comercial são analisados em conjunto com os dados da estrutura industrial da indústria farmacêutica, obtém-se um quadro mais claro da atual fragilidade da base produtiva em saúde. A análise dos diferentes elos da cadeia produtiva do Subsistema de Base Química e Biotecnológica demonstra a elevada disparidade entre a capacidade produtiva e o dinamismo da produção de medicamentos finais e a produção de Insumos Farmacêuticos Ativos (IFAs), que representa um importante gargalo na cadeia produtiva da indústria de base química e biotecnológica.

Mais de $80 \%$ da demanda nacional de IFAs por produção nacional de medicamentos é suprida pela importação oriunda da Europa, da China e da Índia. Um número reduzido de laboratórios farmacêuticos nacionais optou pela verticalização da produção de alguns insumos estratégicos, o que, entretanto, não constitui uma tendência geral entre as empresas do setor farmacêutico.

O segmento farmoquímico é constituído por um universo reduzido de empresas (estima-se que existam cerca de vinte empresas farmoquímicas atuando no Brasil atualmente) que operam sem economias de escala e, muitas vezes, não contam com certificação de Boas Práticas de Fabricação (BPFs) exigida pela Agência Nacional de Vigilância Sanitária (Anvisa). Tais limitações restringem a capacidade dessas empresas de competir com produtores indianos e chineses que operam em maior escala e com menores custos.

Assim, pode-se dizer que o processo de mudança estrutural que é percebido no âmbito do segmento de empresas farmacêuticas não encontra correspondência na produção de fármacos (IFAs). Não obstante, a produção nacional de IFAs representa um componente estratégico no desenvolvimento da cadeia produtiva farmacêutica e na própria busca de soberania na área da saúde.

No Gráfico 14 procura-se ilustrar o gargalo na base produtiva mediante a comparação entre a evolução do tamanho médio (medido pela relação entre o valor da produção e o número de unidades locais) e a da produtividade física (medida pela relação entre o valor da transformação industrial e o pessoal ocupado) para os segmentos farmoquímicos e de medicamentos no período entre 1996 e 2007 . A análise desses indicadores demonstra elevada disparidade entre a escala média de produção em ambos os segmentos. ${ }^{11}$ Dessa forma, verifica-se que o hiato entre a escala de

11 Em 2007, o valor médio da produção anual no segmento farmoquímico era de aproximadamente $\mathrm{R} \$ 12$ milhões, ao passo que no segmento de medicamentos esse valor era de cerca de $\mathrm{R} \$ 45$ milhões. 
produção do segmento de medicamentos e a de insumos farmoquímicos ampliou-se consideravelmente ao longo da última década. Em 2009, o valor médio da produção anual nas empresas do segmento farmoquímico era de aproximadamente $\mathrm{R} \$ 10 \mathrm{mi}-$ lhões, ao passo que no segmento farmacêutico (preparações médicas e medicamentos para uso humano e veterinário) esse valor era de $\mathrm{R} \$ 58$ milhões, ou seja, mais de cinco vezes maior do que naquele segmento.

Gráfico 14 - Relação entre Valor Bruto da Produção (VP) e número de Unidades Locais (UL) e entre 0 Valor da Transformação Industrial (VTI) e a População Ocupada (PO) no segmento farmoquímico e de medicamentos. Brasil - 1996-2007

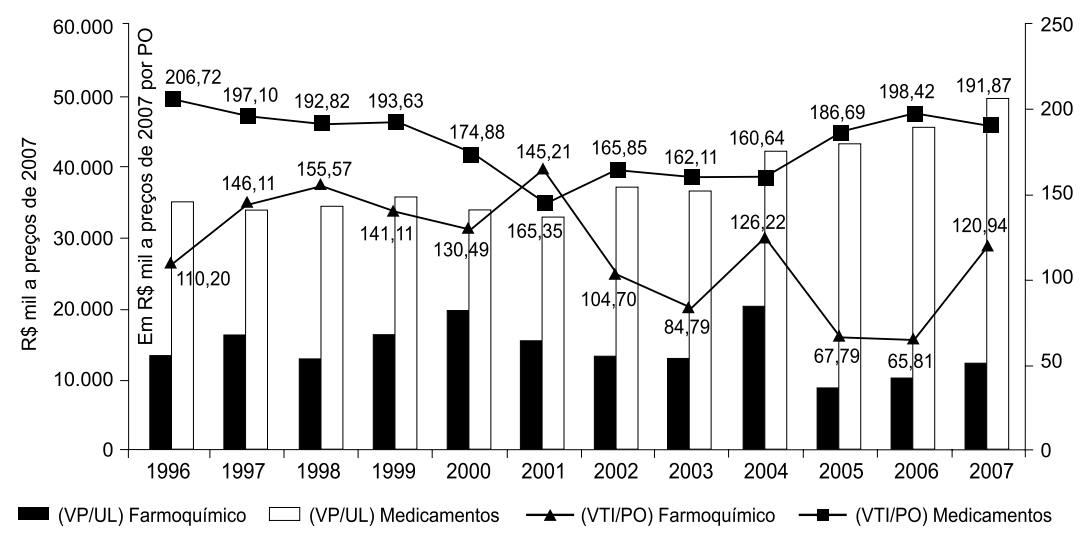

Fonte: elaboração própria a partir dos dados da PIA/IBGE, 2012b.

O gráfico apresenta também a evolução dos níveis de produtividade no segmento de medicamentos e de insumos farmoquímicos, no período 1996-2007, medida em termos da relação entre o Valor da Transformação Industrial (VTI) e o pessoal ocupado. ${ }^{12}$ A produtividade no segmento de medicamentos é consideravelmente maior do que a do segmento farmoquímico ao longo de quase todo o período considerado. Cabe observar o comportamento antagônico nos níveis de produtividade desses dois segmentos entre 1996 e 2001. Nesse período, enquanto a produtividade física no segmento farmoquímico aumentou em cerca de $30 \%$, no segmento de medicamentos ocorreu uma queda nos níveis de produtividade nesse mesmo percentual. Assim, em 2001 a produtividade física do segmento farmoquímico superava aquela do segmento de medicamentos. No caso do segmento de medicamentos a redução no nível de produtividade esteve associada à combinação de forte expansão do pessoal ocupado e queda no valor bruto da produção industrial em termos absolutos. Entretanto, após 2001 verifica-se recuperação na produtividade da produção de medicamentos, impulsionada, possivelmente, pelo

\footnotetext{
${ }^{12}$ A fim de permitir a comparação ao longo do período analisado, considerou-se o valor de transformação industrial a preços constantes de 2007.
} 
crescimento significativo nas vendas de medicamentos genéricos nesse período. Ao mesmo tempo que ocorre queda acentuada nos níveis de produtividade no segmento farmoquímico, verifica-se recuperação na produtividade das atividades de fabricação de medicamentos entre 2001 e 2007.

\section{Esforço Inovativo}

Em termos da capacitação para inovação, a comparação com os padrões internacionais de esforço inovativo da indústria farmacêutica revela que a maior parte dos laboratórios nacionais não tem porte nem recursos em escala suficiente para atuar na ponta do desenvolvimento científico e tecnológico. A Pfizer, uma das maiores empresas farmacêuticas em âmbito mundial, conta com um faturamento de quase US\$ 60 bilhões e investe em P\&D o equivalente a cerca de $16 \%$ do faturamento. Já o faturamento dos maiores laboratórios nacionais situava-se, em 2010, na casa dos R\$ 2 bilhões enquanto que o investimento total do setor farmacêutico em P\&D interno no Brasil foi, de acordo com dados da Pesquisa de Inovação Tecnológica (Pintec/IBGE), da ordem de R\$ 430 milhões em 2008, o que reflete um percentual de dispêndio em P\&D em relação ao faturamento de menos de $2 \%$. Cabe ressaltar, entretanto, que as informações referentes ao esforço inovativo no setor farmacêutico no Brasil contemplam os dispêndios efetuados tanto por laboratórios nacionais como pelas filiais de empresas farmacêuticas multinacionais que atuam no país. Nesse sentido, as limitações no tocante ao esforço inovativo do setor farmacêutico brasileiro não se restrigem à baixa propensão ao investimento em $P \& D$ por parte de empresas nacionais, mas também refletem o fato de que as empresas farmacêuticas multinacionais destinam a atividades de $P \& D$ no país reduzida parcela de recursos.

Da mesma forma, conforme autores como Albuquerque e Cassiolato (2000) e Gadelha e Maldonado (2008), percebe-se um claro descolamento entre o suporte à atividade científica em saúde no Brasil - que segue um padrão internacional - e os resultados em termos da taxa de inovação no setor, que ainda é muito baixa.

Apesar desse hiato na escala de vendas e $P \& D$, a análise do perfil atual de esforço inovativo por parte dos laboratórios farmacêuticos nacionais revela que a busca de inovações incrementais, associadas em particular ao desenvolvimento de medicamentos genéricos, já vem sendo acompanhada de estratégias mais ambiciosas de desenvolvimento de medicamentos e fármacos por rotas biotecnológicas e pela exploração de oportunidades advindas da biodiversidade. O esforço de P\&D interno é complementado com a apropriação extramuros de conhecimento científico e tecnológico, abrangendo os mais diversos formatos organizacionais, desde cooperação com universidades e institutos tecnológicos, acordos de cooperação com fornecedores, licenciamento de tecnologias, patenteamento no Brasil e no exterior, até a constituição de sociedade de $P \& D$. Tal fato reforça a necessidade de se ampliar e consolidar a infraestutura de $P \& D$ em saúde no país a fim de propiciar condições favoráveis ao desenvolvimento de fármacos e medicamentos inovadores. 
A avaliação das novas estratégias inovativas que têm sido adotadas por empresas farmacêuticas nacionais revela, portanto, mudanças qualitativas importantes no perfil de atuação produtiva e comercial que podem contribuir para o processo de consolidação do setor no país. A mudança gradativa no padrão do esforço inovativo das empresas farmacêuticas no Brasil se reflete, em parte, na análise da estrutura de dispêndio em atividades inovativas do setor farmacêutico com base nos dados da Pintec/IBGE.

Por um lado, entre 2000 e 2005 o aumento na taxa de inovação do setor farmacêutico foi acompanhado por uma redução no investimento em atividades inovativas como percentual da RLV do setor. Em 2000, as empresas inovadoras do setor farmacêutico brasileiro investiram 5,67\% da sua RLV em atividades inovativas. Em 2003, esse percentual se reduziu a menos de 4\% e em 2008 voltou a crescer, chegando a 4,89\%. À medida que se focaliza o investimento em atividades de P\&D, tanto internas como externas às empresas, percebe-se uma participação ainda modesta dos gastos das empresas. Em 2000, o dispêndio total em atividades de P\&D das empresas inovadoras do setor totalizou cerca de R\$ 200 milhões, ou 1,48\% da RLV das empresas do setor. Em 2008, esse dispêndio mais do que triplicou, chegando a quase R 620 milhões, ou 2,06\% da RLV.

Por outro lado, em termos da evolução nos gastos internos em P\&D, em 2005 esse tipo de dispêndio representava apenas 0,72\% do total das receitas de vendas, enquanto que em 2008 esse percentual aumentou para 1,44\%. Juntas, as atividades internas e externas de P\&D representaram cerca de $2 \%$ da receita de vendas em 2008 , o equivalente a cerca de $\mathrm{R} \$ 1,5$ bilhão.

Da mesma forma, percebe-se entre 2005 e 2008 um aumento na participação relativa dos gastos internos e externos em $P \& D$ no total do dispêndio em inovação, que passa de 30,5\% em 2005 para 42,2\% em 2008. Tal aumento ocorreu em detrimento dos gastos com máquinas e equipamentos e dos gastos com introdução de inovações no mercado, que tiveram sua participação relativa reduzida, respectivamente, para $25,9 \%$ e $12,3 \%$ em 2008. Assim, embora o dispêndio em atividades inovativas por parte da indústria farmacêutica no Brasil ainda esteja muito aquém do padrão internacional do setor (as empresas farmacêuticas globais investem em média 15\% das vendas em atividades de P\&D), os dados da Pintec/IBGE evidenciam significativa melhora no esforço inovativo do setor, tanto quantitativa (montante investido) quanto em qualitativa (estrutura do dispêndio) (Gráfico 15).

Além da caracterização geral da indústria de farmacêutica como espaço competitivo que condiciona a dinâmica do Subsistema de Base Química e Biotecnológica, é importante destacar algumas das particularidades dos demais segmentos, como os de produção de vacinas, hemoderivados e reagentes para diagnóstico. Apesar de apresentarem, por vezes, peculiaridades, observa-se nesses segmentos uma clara convergência tecnológica, econômica e competitiva, em que as empresas farmacêu- 
ticas líderes invadem os demais segmentos de base química e biotecnológica e os submetem às suas estratégias de inovação. Isso leva alguns autores a afirmar, como nos casos das vacinas (Temporão, 2002; Gadelha, 2002), que os distintos segmentos se tornam espaços de mercado no interior de um oligopólio diferenciado, cuja concorrência se expressa em grupos particulares de produtos (classes terapêuticas, segmentos biotecnológicos etc.).

Gráfico 15 - Estrutura do dispêndio em atividades inovativas no setor farmacêutico. Brasil - 2000, 2003 e 2008 (em \% do dispêndio total)
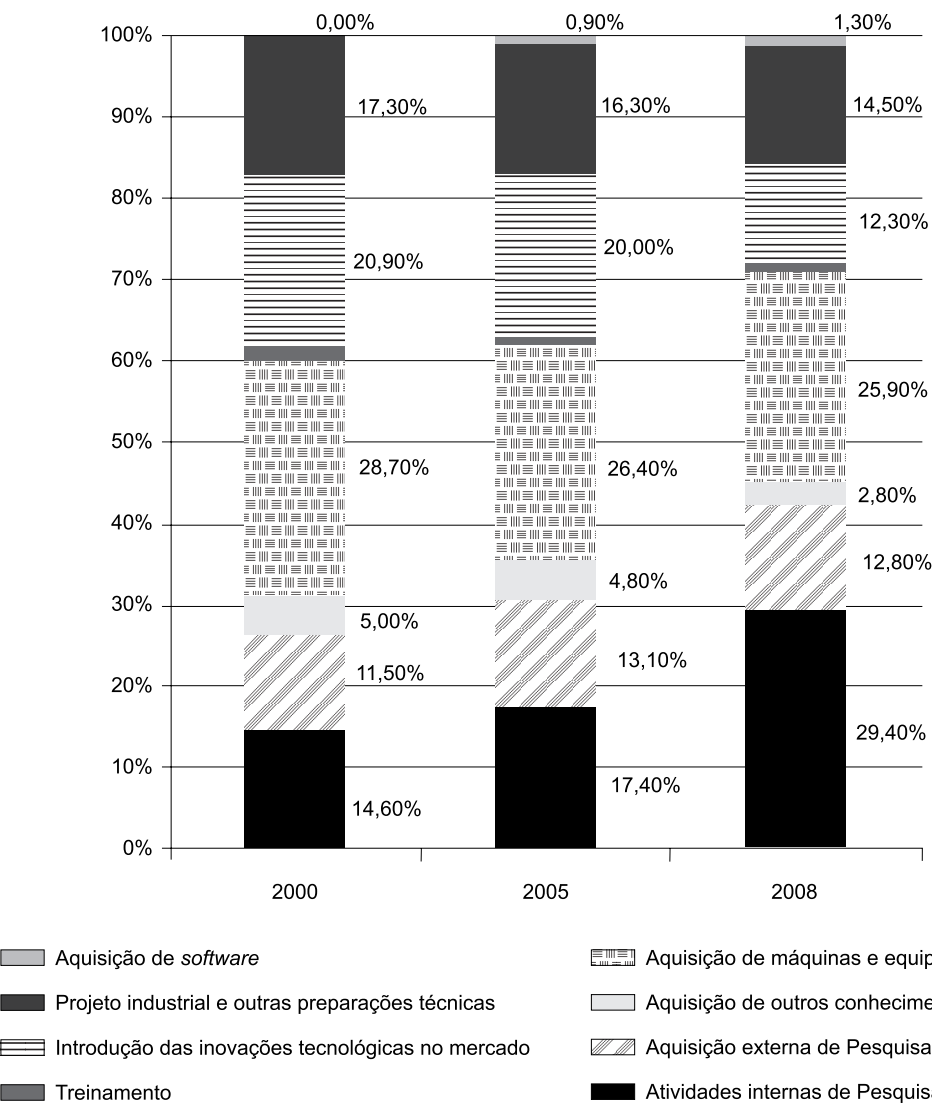

EㅔIII $=$ Aquisição de máquinas e equipamentos

$\square$ Aquisição de outros conhecimentos externos

W $\mathbb{Z}$ Aquisição externa de Pesquisa e Desenvolvimento

Atividades internas de Pesquisa e Desenvolvimento

Fonte: elaboração própria a partir de dados da Pintec/IBGE 2008 (IBGE, 2010b).

Vacinas, Hemoderivados e Reagentes para Diagnóstico: caracterização e tendências

VACINAS

A indústria de vacinas é um dos segmentos do Subsistema de Base Química e Biotecnológica em que o papel do Estado se revela fundamental, tanto no âmbito 
da produção por parte de laboratórios públicos como no tocante ao poder de compra associado às políticas públicas de vacinação. Tais características se refletem no desempenho da balança comercial deste segmento, conforme ilustrado no Gráfico 16. Ao contrário do que ocorreu nos segmentos de medicamentos e insumos farmacêuticos, as importações de vacinas não apresentaram aumento significativo a partir da segunda metade da década de 2000. Entre 2004 e 2009 o montante de importações de vacina aumentou de US\$ 171 milhões para US\$ 303 milhões. O aumento expressivo no montante das importações de vacinas em 2010, de US\$ 1.13 bilhão, é explicado pela campanha de vacinação contra o vírus influenza H1N1 promovida em caráter excepcional pelo MS, que envolveu a compra de dezenas de milhões de doses. Assim, já em 2011 a importação de vacinas se reduz ao patamar de US\$ 560 milhões.

Gráfico 16 - CEIS. Balança comercial de vacinas. Brasil - 1996-2011

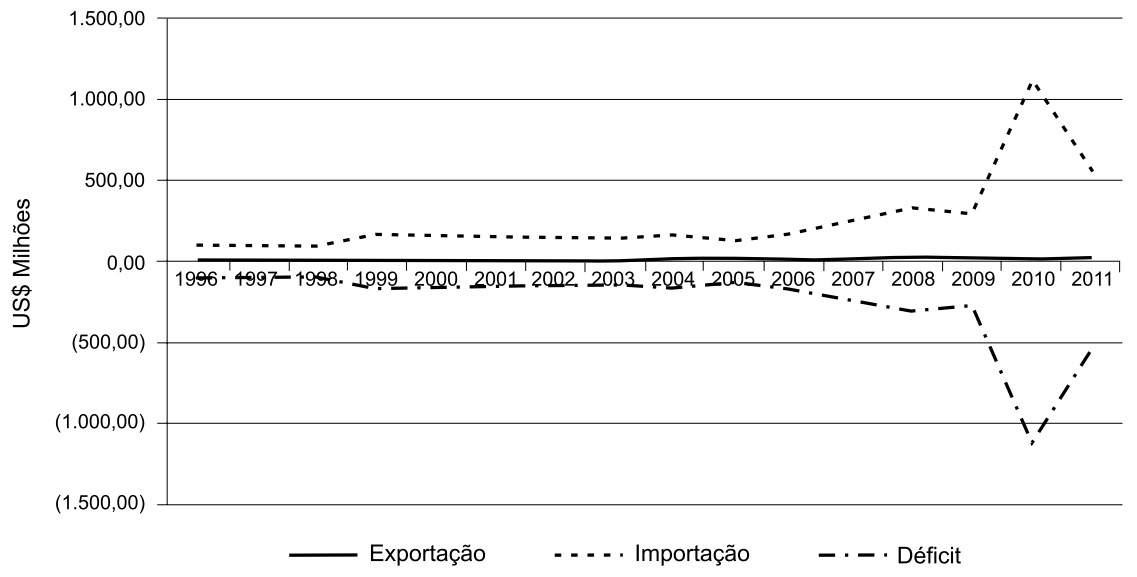

Fonte: elaborado por GIS/Ensp/Fiocruz, 2012, a partir de dados do Alice Web (Brasil. Ministério do Desenvolvimento, Indústria e Comércio Exterior, 2012). Valores em US\$ bilhões atualizados pelo IPC-EUA.

Em âmbito mundial, a crescente complexidade tecnológica dos processos de inovação no segmento de vacinas, associada ao aumento dos custos de P\&D, tem levado a intenso processo de concentração da produção, a qual envolve uma estratégia de articulação entre as grandes empresas farmacêuticas e pequenas empresas de biotecnologia ou instituições de $P \& D$. Dessa forma, a dinâmica competitiva da indústria de vacinas, como mencionado, passa a assumir cada vez mais as características oligopólicas de competição da indústria farmacêutica, em que a capacidade de inovação representa o principal fator competitivo (Baetas, Quental \& Bomtempo, 2007). Em 2010, o montante de vendas no mercado mundial estava estimado em mais de US\$25 bilhões, e as quatro maiores empresas do segmento (GSK, Sanofi, Pfizer e Merck) foram responsáveis por cerca de $80 \%$ desse valor (Evaluate Pharma, 2011). 
É importante destacar que a trajetória de desenvolvimento da indústria de vacinas no Brasil foi marcada, a partir dos anos 80 , pelo predomínio da participação de laboratórios públicos, com destaque para Bio-Manguinhos/Fiocruz e para o Instituto Butantan. Esses laboratórios iniciaram com a fabricação de produtos tecnologicamente mais simples, porém de difícil padronização, e voltados para o atendimento do mercado público brasileiro, como a vacina tríplice bacteriana DTP, a vacina contra o sarampo e a vacina contra febre amarela. Progressivamente, esses produtores passaram a, incorporando técnicas de DNA recombinante, de conjugação, entre outras, produzir vacinas de terceira geração, como a vacina tríplice viral e aquelas contra hepatite B, Haemophilus influenzae tipo B (para meningite, entre outras doenças), gripe e rotavírus, o que representou a entrada mais significativa do país na produção de produtos da moderna biotecnologia em saúde (Temporão \& Gadelha, 2007). ${ }^{13}$

Em 2010, as compras governamentais de vacinas para uso humano eram da ordem de cerca de trezentos milhões de doses, com quatro laboratórios oficiais (BioManguinhos, Butantan, FAP e Funep) sendo responsáveis por cerca de 93\% do número de doses produzidas.

Esse avanço foi possível em virtude de se ter associado um programa de investimento para o aumento da capacidade de oferta interna e para a melhoria da qualidade (o Programa de Autossuficiência Nacional em Imunobiológicos, Pasni, criado em 1985) com a consolidação da demanda nacional no Programa Nacional de Imunizações (PNI). Lançado em 1971, o PNI foi internacionalmente reconhecido por seu desempenho na vacinação em massa em um país com a dimensão populacional e territorial do Brasil, o que constitui uma boa evidência da efetividade das políticas públicas quando adotam uma perspectiva sistêmica, articulando a dimensão serviços de saúde com a dimensão tecnológico-industrial.

Entretanto, apesar dos avanços em termos da capacidade de produção nacional de vacinas e soros, verifica-se ainda elevada dependência externa, sobretudo no tocante ao desenvolvimento endógeno de novos produtos e processos. Parte substantiva dos avanços tecnológicos ainda se restringe à capacitação para produzir, adquirida das empresas farmacêuticas líderes atuantes no segmento, mediante o poder de compra acoplado a contratos de transferência progressiva do ciclo tecnológico, o que explica ainda a importação significava de concentrado vacinal (bulk, equivalente ao princípio ativo farmacêutico), que representa a parte mais significativa das importações de US\$ 560 milhões em 2011.

Assim, a ampliação da participação do país não somente na produção, mas principalmente no conteúdo tecnológico das vacinas produzidas, deve constituir uma

\footnotetext{
${ }^{13}$ De acordo com Gadelha e colaboradores (2009), a importância dessa entrada do setor público na biotecnologia moderna nos anos 90 ganha ainda mais destaque quando se considera o contexto neoliberal em que as iniciativas biotecnológicas mais sofisticadas eram desativadas, como ocorreu no caso da venda e posterior interrupção da produção de insulina por engenharia genética da Biobrás.
} 
prioridade em termos de políticas públicas e está diretamente associada à ampliação dos investimentos em modernização de plantas de produção, formação de quadros e intensificação dos esforços de transferência tecnológica.

No âmbito de laboratórios públicos como Bio-Manguinhos e Butantan, verifica-se um esforço para a introdução de novas vacinas que tanto atendam às demandas do MS para o PNI como permitam ampliar as exportações principalmente para o mercado da América Latina. Nesse aspecto, verifica-se a progressiva inserção desses produtores públicos na produção de vacinas tecnologicamente mais complexas, de terceira geração, tais como aquelas contra hepatite $\mathrm{B}$, gripe, tríplice viral e Haemophilus influenzae tipo B (Gadelha et al., 2009). O Quadro 3 relaciona um conjunto de vacinas virais e bacterianas que devem ser introduzidas no portfólio de produtos de Bio-Manguinhos nos próximos oito anos.

Quadro 3 - Vacinas virais e bacterianas que constituem novos focos de desenvolvimento por BioManguinhos - 2010-2020

\begin{tabular}{|c|c|c|}
\hline $2010-2013$ & 2014-2017 & 2018-2020 \\
\hline $\begin{array}{l}\text { VaCinAS InATIVADAS } \\
\text { Pólio inativada }\end{array}$ & $\begin{array}{l}\text { VaCINAS INATIVADAS } \\
\text { Dengue } \\
\text { Febre amarela }\end{array}$ & $\begin{array}{l}\text { Vacinas InATIVADAS } \\
\text { Hepatite A }\end{array}$ \\
\hline $\begin{array}{l}\text { VACINAS PURIFICADAS } \\
\text { Febre amarela purificada } \\
\text { com dose reduzida }\end{array}$ & $\begin{array}{l}\text { VacinAS RECOMBINANTES } \\
\text { HPV } \\
\text { Influenza pandêmica }\end{array}$ & $\begin{array}{l}\text { VAcINAS REComBinantes } \\
\quad \text { (expressão e vetor viral) } \\
\text { Dengue quimérica } \\
\text { FA-malária } \\
\text { FA-HIV } \\
\text { ETEC-, H. pyllori } \\
\text { Necator americanus }\end{array}$ \\
\hline $\begin{array}{l}\text { VACINAS COMBINADAS } \\
\text { Dupla viral } \\
\text { TVV + varicela } \\
\text { Pentavalente }\end{array}$ & $\begin{array}{l}\text { VaCINAS COMBINADAS } \\
\text { DTP-Hib-HB-IPV }\end{array}$ & $\begin{array}{l}\text { Vacinas COMBINADAS } \\
\text { Meningo ACWY135 + Hib líquida }\end{array}$ \\
\hline $\begin{array}{l}\text { VACINAS LIPOPROTEICAS } \\
\text { Meningo B }\end{array}$ & $\begin{array}{l}\text { VACINAS DE SUBUNIDADE } \\
\text { Influenza pandêmica }\end{array}$ & $\begin{array}{l}\text { VACINA RECOMBINANTE } \\
\text { (expressão em sistema vegetal) } \\
\text { FA }\end{array}$ \\
\hline $\begin{array}{l}\text { VaCinAS ConJugadAS } \\
\text { Meningo C conjugada }\end{array}$ & $\begin{array}{l}\text { Vacinas ConJugadas } \\
\text { Vacina para pneumo conjugada, } \\
\text { além de dez sorotipos }\end{array}$ & $\begin{array}{l}\text { Vacinas conJuGaDAS } \\
\text { Vacinas contra estreptococos e } \\
\text { estafilococos resistentes }\end{array}$ \\
\hline $\begin{array}{l}\text { VaCINAS LÍQUIDAS } \\
\quad \text { Hib } \\
\text { Diarreias }\end{array}$ & & \\
\hline
\end{tabular}

Fonte: Fiocruz, 2011. 
HEMODERIVADOS

A indústria de hemoderivados constitui um dos segmentos da indústria farmacêutica que desenvolvem classes terapêuticas de alta complexidade na área biotecnológica a partir do processamento de plasma humano. Em nosso país, a principal peculiaridade deste segmento está associada ao fato de a Constituição brasileira proibir a comercialização de sangue e derivados. Em âmbito internacional a produção de hemoderivados ocorre em um grupo restrito de países e está concentrada em poucos produtores, a exemplo do que ocorre no caso da produção de determinadas classes terapêuticas de medicamentos.

No Brasil, apesar da existência de um fornecimento potencial de quatrocentos mil litros de plasma por ano para fracionamento, o mercado depende fortemente de importações. Por esse motivo o MS deu início, em 2001, a um programa para aproveitamento desse plasma recorrendo à contratação de empresas estrangeiras para execução de serviços de fracionamento. Entretanto, tal estratégia levou a um crescimento explosivo do déficit comercial no segmento de hemoderivados, conforme se pode observar no Gráfico 17. Em 2011, a importação de hemoderivados representava US\$ 1.7 bilhão, sendo responsável por 17\% do total do déficit da balança comercial do Complexo da Saúde.

Gráfico 17 - CEIS. Balança comercial de hemoderivados. Brasil - 1996-2011

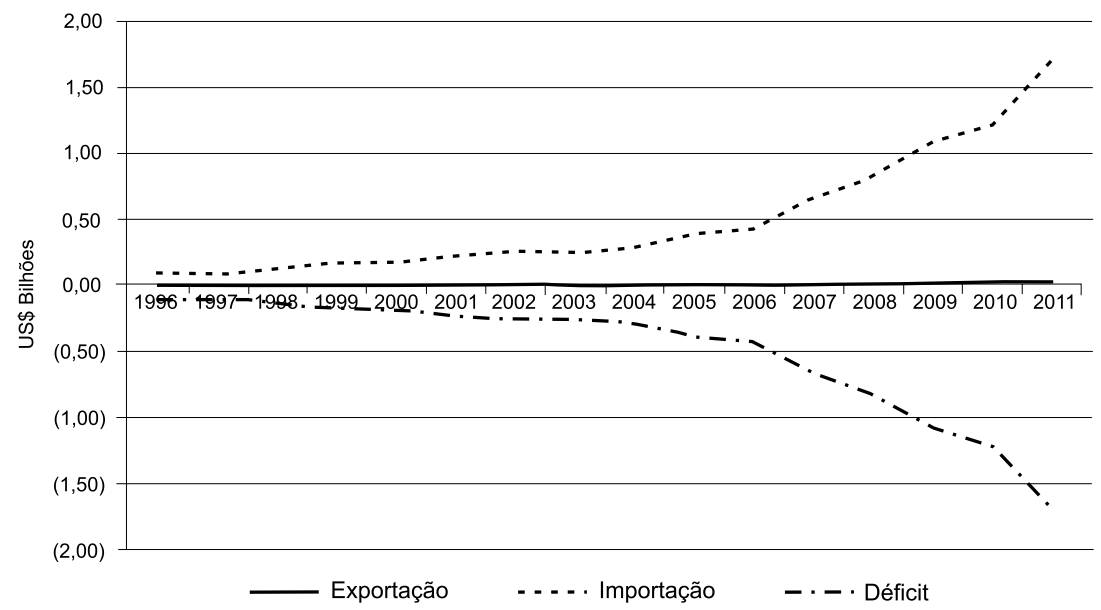

Fonte: elaborado por GIS/Ensp/Fiocruz, 2012, a partir de dados do Alice Web (Brasil. Ministério do Desenvolvimento, Indústria e Comércio Exterior, 2012). Valores em US\$ bilhões atualizados pelo IPC-EUA.

Dentre os itens de maior valor unitário e peso no valor do déficit de hemoderivados encontram-se os anticorpos humanos (NCM 30021038), imunoglobulina anti-Rh (NCM 30021022), plasmina (NCM30021032) e o interferon beta (NCM 30021036). 
Atualmente, a principal iniciativa para ampliar as atividades de fracionamento de plasma no Brasil está associada ao início das atividades da Empresa Brasileira de Hemoderivados e Biotecnologia (Hemobrás), criada em 2004 pelo MS como parte da estratégia brasileira para a obtenção de autossuficiência na produção de hemoderivados.

Orçada em R\$ 540 milhões, a planta industrial da Hemobrás contará com capacidade de processamento anual de quinhentos mil litros de plasma. $O$ início de suas atividades está previsto para 2014, e o grande desafio se concentra na articulação desse investimento com a capacidade tecnológica e de inovação. Dentre os medicamentos a serem produzidos estão: albumina, utilizada em pacientes queimados ou com cirrose e em cirurgias de grande porte; imunoglobulina, que funciona como anticorpo para pessoas com organismo sem defesa imunológica; fatores de coagulação VIII e IX, complexo protrombínico e fator de Von Willebrand, destinado a pessoas com hemofilia (Hemobrás, 2012).

\section{REAGENTES PARA DIAGNÓSTICO}

Em âmbito mundial, a indústria de reagentes para diagnóstico in vitro (DIV) movimenta em torno de 25 bilhões de dólares anuais, com taxas estimadas de crescimento que variam entre $5 \%$ e $6 \%$ ao ano nos três maiores mercados mundiais (Europa, EUA e Japão). Trata-se de um segmento altamente concentrado, no qual aproximadamente 15 empresas acumulam 90\% do faturamento global. Da mesma forma, apresenta elevada taxa de fusões e aquisições motivadas principalmente por posicionamentos globais, como no caso da Siemens, que adquiriu a Bayer (ex-2 $2^{a}$ maior), a Dade Bhering (ex-5 $5^{\text {a }}$ maior) e a DPC (ex- $12^{\text {a }}$ maior), tornando-se a segunda maior empresa de diagnósticos mundial, atrás apenas da Roche (Paiva, 2009).

O movimento crescente de aquisições e fusões entre empresas do segmento de reagentes, além de estratégico para o seu reposicionamento competitivo, cria barreiras à entrada de novas empresas no mercado. O lançamento de novas tecnologias, ameaças de produtos substitutos e as patentes depositadas são continuamente monitorados e, quando necessário, as grandes empresas atuam de maneira agressiva e adquirem ou se associam às empresas com potencial inovador.

o Brasil constitui atualmente o oitavo maior mercado de reagentes para DIV em nível mundial e tem atraído continuamente empresas multinacionais, com vista à expansão do mercado local aliada à expansão dos gastos com saúde pública. Hoje, as dez maiores empresas mundiais em reagentes para diagnóstico têm escritórios ou fábrica no Brasil. O setor público representa cerca de $60 \%$ da demanda dos fabricantes de reagentes para diagnóstico no país. Conforme destacado por Paiva (2009), em alguns casos a compra de reagentes pelo setor público está vinculada às regulamentações do país referentes aos algoritmos de testes para diagnósticos de Aids, que são padronizados. A principal estratégia de mercado das empresas multinacionais que atuam no país é oferecer o sistema de comodato de equipamentos 
com consumo mínimo de kits mensais pelos estabelecimentos de saúde que, com algumas exceções, firmam os contratos em equipamentos "fechados" (não operam com kits de outros fornecedores). Essa previsibilidade aliada à forma de condução do processo de aquisição e ao poder de compra do Estado resulta em uma competição mais acirrada entre os fornecedores da indústria em relação a preço, qualidade e assessoria técnica prestada. Contudo, por terem expertise em segmentos diferentes, as empresas se estabelecem em nichos particulares das demandas públicas.

Tendências de Investimentos: síntese do panorama atual

o panorama atual da indústria de base química e biotecnológica em saúde no Brasil permite traçar um quadro de referência para a compreensão dos principais desafios e oportunidades que se colocam para a ampliação dos investimentos em sua indústria de base química e biotecnológica nos próximos anos (Vargas et al., 2010; Gadelha et al., 2009):

- A análise da balança comercial de fármacos e medicamentos revela a existência de um déficit estrutural, que se amplia consideravelmente desde a segunda metade da década de 2000 e atingiu um montante de quase US\$ 8 bilhões em $2011 .{ }^{14} \mathrm{Um}$ dos fatores que têm contribuído para esse aumento exponencial do déficit na balança comercial, além da própria expansão dos gastos com saúde, está associado à importação de produtos de base biotecnológica. ${ }^{15}$

- A análise da estrutura industrial da indústria farmacêutica nacional revela a existência de importantes gargalos na cadeia produtiva, particularmente no tocante à produção de IFAs. Estima-se que a produção nacional de fármacos atenda a menos de $17 \%$ da demanda nacional. Ademais, os problemas de base industrial e escala de produção no segmento se somam às fortes pressões competitivas oriundas das importações de IFAs de produtores chineses e indianos.

- A retomada recente no crescimento do setor farmacêutico, fomentada pela expansão do mercado de medicamentos genéricos, viabilizou o fortalecimento das empresas nacionais, mas também tem constituído um forte estímulo à entrada dos grandes laboratórios multinacionais no mercado brasileiro mediante aquisição de empresas locais. Tal quadro tem induzido um processo

\footnotetext{
${ }^{14}$ De acordo com dados do GIS/Ensp/Fiocruz sobre a balança comercial do CEIS.

15 As compras de medicamentos de componente especializado concentram grande parte da demanda de produtos biológicos e totalizavam $\mathrm{R} \$ 3,2$ bilhões em 2010 , ou cerca de $30 \%$ do montante total de compras do MS. De acordo com dados do DECIIS/SCTIE/MS, a análise do perfil atual da aquisição de medicamentos do componente especializado da assistência farmacêutica por parte do MS revela que, em 2010, a aquisição de biofármacos representou 3,70\% do volume em unidades de medicamentos adquiridas e $31,97 \%$ do valor das aquisições em reais (Brasil. Ministério da Saúde, 2012).
} 
de mudança estrutural no setor farmacêutico nacional, pautado por novas estratégias competitivas e inovativas dos laboratórios nacionais. Não obstante, verifica-se que as empresas do setor farmacêutico no Brasil ainda apresentam investimentos reduzidos em atividades inovativas e de $P \& D$, em relação tanto ao padrão internacional da indústria farmacêutica quanto aos setores mais dinâmicos da indústria brasileira.

- O Brasil ainda responde por uma parcela mínima dos gastos em P\&D efetuados pelas grandes empresas farmacêuticas globais. Assim, a despeito da presença marcante de empresas americanas no mercado brasileiro, que representa $2 \%$ do mercado mundial, o Brasil responde por $0,2 \%$ dos gastos em P\&D dessas empresas (Gadelha et al., 2009).

- A estrutura produtiva em saúde no Brasil conta com o destacado papel desempenhado pelos laboratórios oficiais na PNS, na produção de medicamentos para o SUS, no suporte à regulação ou no processo de ampliação da capacitação tecnológica nacional. Esse papel tem sido reforçado pelas novas políticas que resgatam o poder de compra do Estado como mecanismo de fortalecimento da capacitação tecnológica e industrial em áreas e produtos estratégicos para o sistema nacional da saúde.

- Verifica-se ainda elevada concentração da estrutura produtiva da indústria farmacêutica nas regiões Sul e Sudeste, particularmente nos estados de São Paulo, Rio de Janeiro e Minas Gerais. Essa concentração da estrutura produtiva industrial também reflete uma forte assimetria na distribuição da infraestrutura científica e tecnológica ligada ao esforço de pesquisa, desenvolvimento e inovação em saúde.

- Finalmente, a existência desse déficit também traz implicações importantes em termos da vulnerabilidade do sistema nacional de saúde e, consequentemente da soberania nacional na área da saúde. Há um consenso quanto à necessidade de aliar a expansão da base produtiva de fármacos e medicamentos a estratégias ativas de incorporação de novas plataformas tecnológicas, particularmente aquelas relacionadas à biotecnologia, em prol de melhor articulação entre as políticas sociais e de inovação.

Com base nesse quadro geral de referência, na próxima seção são examinadas as perspectivas a médio e a longo prazos para a ampliação de investimentos na indústria de base química e biotecnológica em saúde, tendo como eixos de análise o crescimento do mercado nacional e global e as novas estratégias produtivas e inovativas dos laboratórios nacionais. 


\section{PERSPECTIVAS A MÉDIO E LONGO PRAZOS PARA OS INVESTIMENTOS}

\section{Perspectivas a Médio Prazo: cenário possível}

As perspectivas de expansão dos investimentos induzidos e estratégicos na indústria de base química e biotecnológica em saúde a médio prazo encontramse condicionadas por um conjunto de fatores relacionados tanto às estratégias empresariais como à evolução recente da política macro, industrial e de saúde, no Brasil e aos seus impactos no Complexo Industrial da Saúde. Tais fatores são analisados a seguir em torno de dois eixos centrais: as perspectivas de crescimento do mercado farmacêutico global e nacional; as mudanças recentes nas estratégias empresariais das empresas farmacêuticas nacionais. Outro fator relevante e que apresenta forte inter-relação com os demais já mencionados reside nas políticas de apoio ao CEIS. Essa questão será analisada na seção final, sobre proposição de políticas.

\section{Perspectivas de crescimento dO mercado global e nacional}

Um primeiro fator de crucial importância nas perspectivas de investimento diz respeito às tendências de crescimento do mercado farmacêutico mundial e nacional. Em âmbito global, estima-se que o mercado farmacêutico deverá apresentar uma taxa média de crescimento anual entre 3 e 6 \% no período 2011-2015. O principal vetor desse crescimento encontra-se associado ao dinamismo dos mercados emergentes como Brasil, China, Índia, entre outros. De acordo com estudos recentes desenvolvidos no âmbito de consultorias internacionais (IMS Health, 2011), os mercados farmacêuticos emergentes (Bric, México, Turquia, Polônia, Venezuela, Argentina, Indonésia, África do Sul, Tailândia, Romênia, Egito, Ucrânia, Paquistão e Vietnã) devem contribuir com cerca de $66 \%$ do crescimento do mercado farmacêutico global no período de 2010 a 2015, ao passo que a contribuição estimada de mercados da Europa será praticamente nula e a dos EUA, de $12 \%$. No caso do Brasil, estima-se uma taxa de crescimento composto anual entre 10 e 13\%, que, apesar de inferior ao crescimento estimado para outros mercados farmacêuticos emergentes como o da China (19-22\%) ou da Índia (14-17\%), é superior à dos mercados farmacêuticos maduros (1-4\%). No âmbito dos mercados emergentes, estima-se que o gasto com medicamentos tende a diminuir e a se concentrar bastante nos medicamentos genéricos, conforme ilustra o gráfico seguinte. No caso do Brasil, estima-se que o gasto total com medicamentos deve cair de US\$22.9 bilhões em 2011 para US $\$ 16.8$ bilhões em 2015, ao passo que o gasto com medicamentos de referência deve cair de US\$ 6.5 bilhões para US\$ 1.6 bilhão (Gráfico 18).

Quanto às perspectivas do mercado farmacêutico brasileiro, é importante destacar dois elementos que deverão operar como indutores de seu crescimento nos próximos anos. o primeiro, já discutido nas seções precedentes, está relacionado com o fim da vigência de patentes para um volume crescente de medicamentos. Entretanto, embora ainda represente uma importante janela de oportunidade para empresas farmacêuticas nacionais, a estratégia de crescimento mediante a comercialização de medicamentos 
genéricos já enfrenta limitações, na medida em que foi assimilada pelas grandes multinacionais farmacêuticas que passaram a investir no lançamento de seus próprios genéricos antes mesmo do vencimento da patente de seus medicamentos de marca. Um segundo fator indutor do crescimento do mercado farmacêutico brasileiro está relacionado à manutenção dos gastos públicos em saúde. $O$ aumento sustentado nos gastos públicos com saúde no Brasil no decorrer dos últimos anos tem sido importante fator de estímulo à expansão dos investimentos nos diferentes segmentos que integram a indústria de base química e biotecnológica ligada ao complexo da saúde.

Gráfico 18 - Gastos em medicamentos nos mercados farmacêuticos emergentes - 2010 e 2015 (em US\$ bilhões)
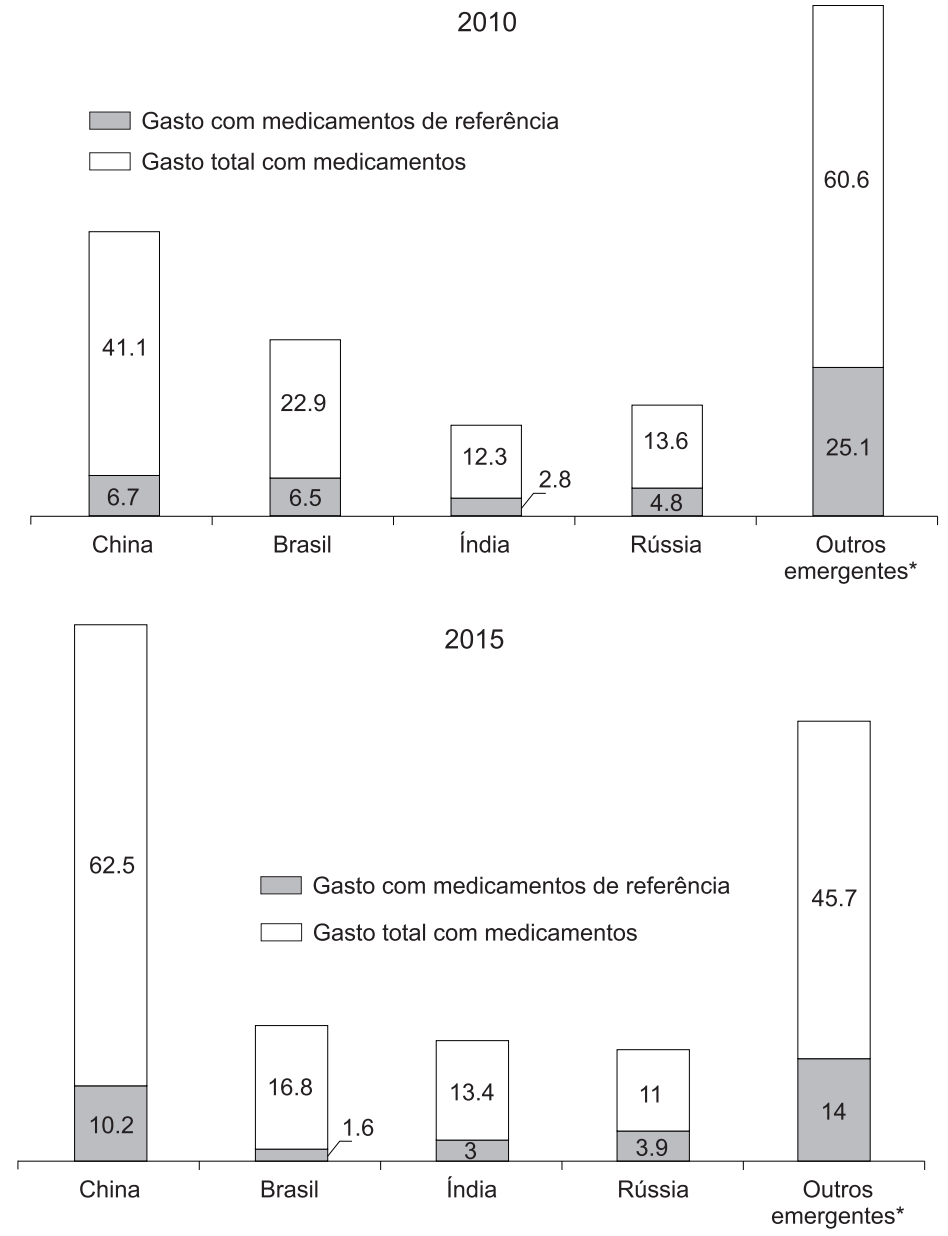

* México, Turquia, Polônia, Venezuela, Argentina, Indonésia, África do Sul, Tailândia, Romênia, Egito, Ucrânia, Paquistão e Vietnã. Fonte: GIS/Ensp/Fiocruz, a partir de dados da IMS Health, 2011. 
O Gráfico 19 mostra o aumento das compras públicas entre 2003 e 2011 e apresenta tanto a evolução do montante total das compras públicas no período, equivalente a mais de $\mathrm{R} \$ 10$ bilhões em 2010, como a parcela correspondente às compras de soros, vacinas, fatores de coagulação e outros produtos que integram as aquisições de medicamentos de componente especializado. Cabe ressaltar que a compra de medicamentos de componente especializado concentra grande parte da demanda de produtos biológicos e totalizou $\mathrm{R} \$ 3,2$ bilhões em 2010, ou cerca de $30 \%$ do montante total de compras do MS. De acordo com dados do Departamento do Complexo Industrial e Inovação em Saúde (DECIIS/SCTIE/MS), a análise do perfil atual da aquisição de medicamentos do componente especializado da assistência farmacêutica por parte do MS revela que, em 2010, a aquisição de biofármacos representou 3,70\% do volume em unidades de medicamentos adquiridas e $31,97 \%$ do valor das aquisições em reais (Brasil. Ministério da Saúde, 2012).

Gráfico 19 - Compras públicas em saúde do Ministério da Saúde. Brasil - 2003-2011

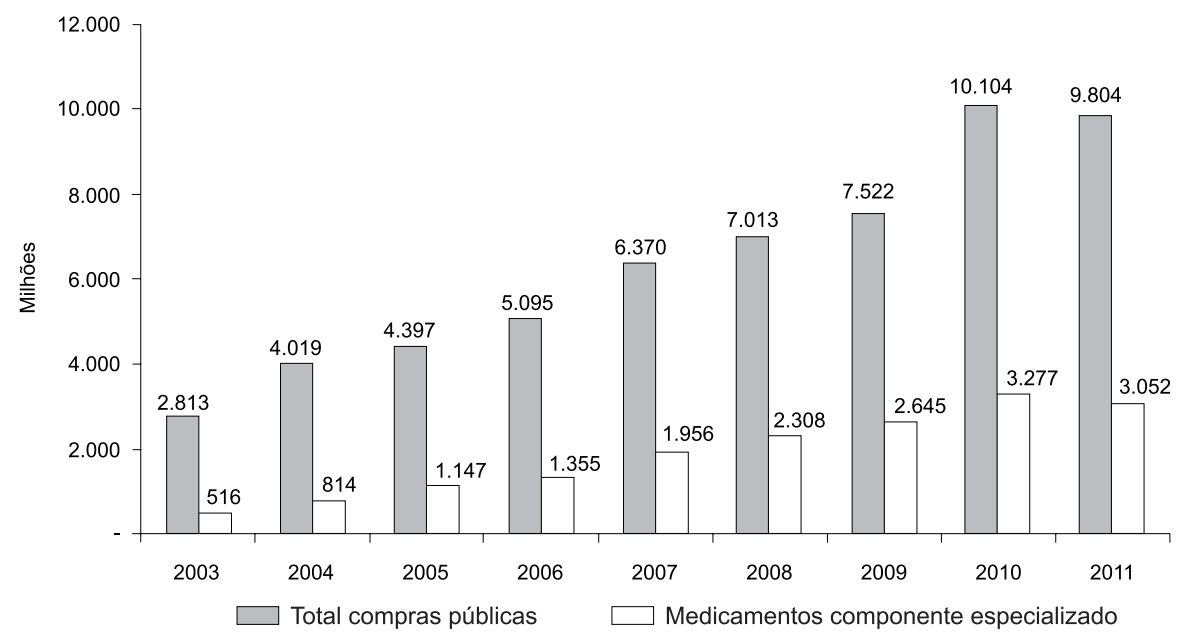

Fonte: Departamento do Complexo Industrial e Inovação em Saúde (DECIIS) e Secretaria de Vigilância em Saúde (SVS) do Ministério da Saúde.

No segmento de vacinas, em que laboratórios públicos têm amplo espaço de atuação, a evolução das compras públicas entre 2004 e 2010 mostra um aumento expressivo, com o montante total de aquisições tendo chegado a US\$2.328 bilhões em 2010. Adicionalmente, ao contrário do contexto que caracteriza o déficit estrutural na balança comercial dos segmentos de medicamentos, fármacos e hemoderivados, no segmento de vacinas o país já conta com uma infraestrutura pública de produção que atende a boa parte da demanda pública doméstica, apesar da clara necessidade de aumento do conteúdo tecnológico da produção nacional. 


\section{MUdANÇAS NAS ESTRATÉGIAS EMPRESARIAIS}

Não obstante os gargalos e limitações, aqui indicados, na configuração atual da base produtiva em saúde no Brasil, é possível constatar um processo de transformação estrutural em curso na indústria de base química e biotecnológica no país que envolve importantes mudanças nas estratégias de capacitação produtiva e inovativa de produtores nacionais.

O crescimento das empresas farmacêuticas nacionais vem sendo reforçado por investimentos em expansão da capacidade produtiva, tanto pela ampliação de plantas quanto pelas aquisições de outras empresas no Brasil e no exterior. Tendo em vista o período recente, a construção e expansão de unidades fabris da Cristália e EMS exemplificam o primeiro ponto. A aquisição da Neoquímica pela Hypermarcas e da Segmenta pela Eurofarma exemplifica o segundo. Esse movimento visa também, entre outros objetivos, à diferenciação e ampliação do portfólio de produtos das empresas. A incorporação da Segmenta, com forte atuação na área de soro, serviu para complementar o portfólio da Eurofarma na área hospitalar, o que também inclui medicamentos injetáveis e antibióticos.

Além do investimento em expansão de plantas, estratégias de internacionalização também estão em curso e têm como foco inicial os países da América Latina. A Cristália, por exemplo, fechou em 2011 a compra da farmacêutica argentina Ima, especializada em oncológicos, no que constituiu a primeira aquisição da empresa fora do Brasil, com o objetivo de exportar princípios ativos na área de oncologia para a América Latina. A Eurofarma, por sua vez, iniciou seu processo de internacionalização ainda em 2009, com a aquisição do laboratório Quesada. Em 2010, comprou os laboratórios Gautier, no Uruguai, e Volta, no Chile. Para 2012, consta dos planos da empresa a construção de uma fábrica na Argentina, que é considerada um país com mercado fechado e concentração de produtores locais. Da mesma forma, trata-se de um mercado estratégico, pois é o terceiro maior mercado de medicamentos da América, após Brasil e México.

A busca de escala na produção e comercialização também tem levado à formação de parcerias específicas na área comercial. Em agosto de 2011, a Cristália e a Eurofarma já haviam firmado uma joint venture para a criação da Supera, com o objetivo de negociar uma parte dos produtos desenvolvidos pelas duas companhias. Já no início de 2012, a Supera formou uma nova joint venture com a multinacional americana MSD (Merck \& Co) para a criação de uma nova empresa, a Supera RX, que passou a contar com portfólio com cerca de trinta medicamentos e deverá incorporar, a médio prazo, remédios inovadores das três farmacêuticas. A MSD terá participação de $51 \%$ nessa nova empresa. Cristália e Eurofarma ficam com 24,5\% cada. A Supera RX deverá absorver boa parte do pipeline (produtos em desenvolvimento) de suas empresas controladoras, que vão manter seus negócios independentes da companhia recém-criada. 
Em termos das estratégias de consolidação patrimonial, associadas, nesse caso, com a busca de capacitação na produção de biológicos, cabe destacar ainda o esforço recente de criação de uma big pharma nacional a partir da joint venture entre alguns dos principais laboratórios farmacêuticos brasileiros com vista ao ingresso no mercado de medicamentos biológicos. Tal iniciativa conta com a articulação e apoio do Banco Nacional de Desenvolvimento Econômico e Social (BNDES) e previa originalmente a participação de oitos laboratórios nacionais. Entretanto, diferenças no tocante às estratégias de inovação permitem identificar dois grupos com enfoques distintos sobre a forma de ingresso nas rotas biotecnológicas de produção. De um lado, encontra-se a proposta de uma joint venture formada pelos laboratórios nacionais Aché, EMS, União Química e a companhia Hypermarcas para criação do BioBrasil, voltado para a produção de medicamentos biológicos de segunda geração mediante uma estratégia do tipo greenfield. De outro, encontra-se uma segunda proposta voltada para a criação de uma joint venture formada pelos laboratórios Biolab, Cristália, Eurofarma e Libbs, que optaram por iniciar sua produção com um portfólio de produtos biotecnológicos de primeira geração (como hormônios de crescimento, interferons e colagenase, por exemplo). As empresas desse segundo grupo já contam com iniciativas na produção de medicamentos por rota biotecnológica de primeira geração - Cristália e Eurofarma já possuem unidade de biotecnologia no país, e Biolab e Eurofarma também criaram, em 2007, uma empresa de pesquisa, a Incrementa -, e consideram que a entrada nos biofármacos de segunda geração passa pelo acúmulo de competências nas rotas de produção de medicamentos biológicos de primeira geração. Ambas as iniciativas deverão contar com apoio financeiro do BNDES (da ordem de $R \$ 400$ a $R \$ 500$ milhões), ainda que no caso da BioBrasil esse apoio envolva a participação acionária por intermédio do BNDES Participações, enquanto que no segundo caso o aporte financeiro do BNDES se dará mediante financiamento.

Em termos da capacitação para inovação, além dos pontos já mencionados na análise sobre o panorama nacional, estudo recente sobre a dinâmica de inovação na indústria farmacêutica paulista (Gadelha, Maldonado \& Vargas, 2008) enfatiza e corrobora o processo de mudança estrutural com base em uma avaliação das novas estratégias competitivas e inovativas que têm sido adotadas por empresas farmacêuticas nacionais, ${ }^{16}$ apresentada no Quadro 4.

16 Tal avaliação foi feita com base em um conjunto de entrevistas que envolveu empresas de grande porte como Aché, Medley e Eurofarma, que ocupam posições de liderança no mercado farmacêutico nacional. Para maiores detalhes sobre a metodologia e escopo desse estudo, ver http://www.ipt.br/atividades/pit/notas/files/Industria_Farmaceutica.pdf. 
Quadro 4 - Estratégias competitivas e inovativas em algumas empresas nacionais líderes do setor farmacêutico

\begin{tabular}{|c|c|c|}
\hline EMPRESA & ATIVIDADES DESTACADAS & ESTRATÉGIAS COMPETITIVAS/INOVATIVAS \\
\hline Aché & $\begin{array}{l}\text { Medicamentos de marca sob prescriçãa, } \\
\text { medicamentos isentos de prescrição, genéricos } \\
\text { e fitoterápicos }\end{array}$ & $\begin{array}{l}\text { - Crescimento horizontal via fusões e aquisições. } \\
\text { - Diferenciação de produtos/ampliação do porttólio. } \\
\text { - Joint venture com empresa multinacional em bio- } \\
\text { tecnologia. } \\
\text { - Expansão dos investimentos em P\&D com expansão } \\
\text { das áreas pesquisadas. } \\
\text { - Investimentos em promoção de vendas. }\end{array}$ \\
\hline Eurofarma & $\begin{array}{l}\text { Medicamentos de marca sob prescrição e } \\
\text { genéricos }\end{array}$ & $\begin{array}{l}\text { - Internacionalização da empresa na América Latina } \\
\text { via expansão de exportações e aquisições de } \\
\text { empresas locais (Colômbia e Argentina, p. ex.). } \\
\text { - Aquisição de participaçãa acionária de empresa } \\
\text { portuguesa. } \\
\text { - Construção e certificação de nova unidade fabril. } \\
\text { - Investimentos em biotecnologia. }\end{array}$ \\
\hline Medley & $\begin{array}{l}\text { Medicamentos de marca sob prescrição, } \\
\text { genéricos e similares }\end{array}$ & $\begin{array}{l}\text { - Ampliação da inserção no mercado de genéricos por } \\
\text { meio da expansão nos gastos em P\&D e do aumento } \\
\text { do volume de produção. } \\
\text { - Investimento estimado de mais de R\$ } 100 \text { milhões } \\
\text { em novas instalações, equipamentos e P\&D. } \\
\text { - Capacitação de recursos humanos. } \\
\text { - Abertura do capital. }\end{array}$ \\
\hline Biolab-Sanus* & $\begin{array}{l}\text { Medicamentos de marca sob prescrição e } \\
\text { similares }\end{array}$ & $\begin{array}{l}\text { - Crescimento horizontal via fusões e aquisições. } \\
\text { - Diferenciação de produtos. } \\
\text { - Diversificaçãa, para a área de alimentos. } \\
\text { - Reforço das linhhas existentes em cosmecêutica. } \\
\text { - Desenvolvimento de novas tecnologias de produção } \\
\text { (pellets e nanotecnologia). }\end{array}$ \\
\hline Coinfar** & P\&D & $\begin{array}{l}\text { - Investimento em novas plataformas tecnológicas } \\
\text { para desenvolvimento de moléculas próprias. } \\
\text { - Investimento em infraestrutura e internalização de } \\
\text { competências de screening e de desenvolvimento de } \\
\text { produtos (escala piloto) em biotecnologia. }\end{array}$ \\
\hline
\end{tabular}

* Adquiriu a empresa farmoquímica Sintefina.

** Engloba Aché, Eurofarma e Biolab-Sanus.

Fonte: Gadelha, Maldonado e Vargas, 2008.

Em síntese, dentre as novas estratégias competitivas e inovativas que vêm sendo adotadas pelas empresas e que devem vir a pautar os investimentos na indústria de base química e biotecnológica em saúde a médio prazo, é possível destacar: 
- Crescimento horizontal via fusões e aquisições de concorrentes nacionais visando à diferenciação de produtos/ampliação do portfólio.

- Processos de internacionalização por meio da expansão de exportações e aquisições de empresas farmacêuticas, principalmente em países da América Latina (Argentina, Chile, Colômbia, Uruguai etc.).

- Expansão dos investimentos em P\&D com foco na produção de biológicos de primeira e segunda gerações.

- Construção e certificação de novas unidades fabris.

- Joint ventures com empresas multinacionais na área de biotecnologia.

- Investimentos em promoção de vendas por meio de joint ventures e parceiras entre laboratórios farmacêuticos nacionais e multinacionais.

O detalhamento das estratégias recentes que vêm sendo adotadas por uma parte dos laboratórios farmacêuticos nacionais é apresentada no Box 1, tomando-se como exemplo a trajetória recente de capacitação do laboratório Cristália.

Box 1 - As novas estratégias dos laboratórios nacionais: 0 caso da Cristália Produtos Químicos Farmacêuticos Ltda.

A experiência do Laboratório Cristália constitui um bom exemplo do esforço de capacitação produtiva e tecnológica que vem sendo empreendido pelos principais laboratórios farmacêuticos nacionais.

0 Cristália, fundado em 1972, é hoje um dos principais laboratórios nacionais do país, com faturamento anual em torno de $\mathrm{R} \$ 600$ milhões. Atua com foco no mercado hospitalar, com a produção de anestésicos, narcoanalgésicos e adjuvantes (são 360 apresentações), sendo responsável pela venda de $50 \%$ da venda de anestésicos no país.

Além de contar com uma planta farmacêutica e farmoquímica (que produz 33\% dos IFAs utilizados na produção), a empresa possui um centro de PD\&l inaugurado em 2009 e é um dos poucos laboratórios farmacêuticos brasileiros que realiza a cadeia completa de PD\&l, desde a concepção do projeto e desenvolvimento do princípio ativo até a disponibilização do medicamento no mercado. 0 s gastos em $P \& D$ representam cerca de $6 \%$ das vendas, um percentual muito superior à média nacional, de acordo com dados da Pintec/IBGE. Além disso, a empresa tem investido na expansão das plantas industriais. 
Box 1 - As novas estratégias dos laboratórios nacionais: 0 caso da Cristália Produtos Químicos Farmacêuticos Ltda. ( continuação )

Em termos de gestão da inovação, além dos investimentos em atividades internas de P\&D a empresa conta com uma estratégia de busca de competências extramuros que inclui a manutenção de um conselho científico permanente com membros da empresa e pesquisadores externos. Esse conselho constitui uma interface importante com universidades e centros tecnológicos. As estratégias da empresa para a produção de biológicos incluem produtos de primeira geração como colagenase e hormônios de crescimento, ora em fase avançada de desenvolvimento. A Cristália mantém uma estratégia de patenteamento no exterior e já conta com mais de trinta patentes, registradas em vários países (EUA, Índia, México, Argentina e China, entre outros).

De acordo com informações recentes do MS, o laboratório Cristália conta, atualmente, com a participação em 11 parceiras para desenvolvimento produtivo envolvendo laboratórios públicos como Lafepe, Hemobrás, Furp e BahiaFarma.

Por fim, a estratégia de crescimento do Cristália envolve também o estabelecimento de joint venture com concorrentes nacionais (Eurofarma e Merck) para comercialização conjunta de produtos e a internacionalização mediante a aquisição de laboratórios no exterior, mais especificamente a compra, em 2011, da farmacêutica argentina Ima, especializada em oncologia, a primeira aquisição da empresa nacional fora do Brasil.

Fonte: elaboração própria com base em entrevistas realizadas durante pesquisa de campo.

Por fim, é possível que, mantidas as tendências de crescimento do mercado e de mudança nas estratégias empresariais, o processo de ajustamento na indústria farmacêutica nacional venha a contemplar um conjunto de transformações que, no cenário a médio prazo, podem envolver:

- A ampliação da capacidade produtiva, porém sem o adensamento da cadeia.

- A consolidação patrimonial de empresas nacionais estimulada pelo aumento das pressões competitivas no mercado de genéricos.

- O aumento da capacitação para inovações de caráter incremental.

- O desenvolvimento de novas plataformas tecnológicas em biotecnologia associada ao papel da infraestrutura tecnológica pública (ex. CDTS/Fiocruz: genômica, proteômica, microarranjos e nanotecnologias etc.).

Os impactos esperados dos investimentos sobre o subsistema, bem como os determinantes necessários para que esse processo de transformação estrutural seja viabilizado a médio prazo, também são sintetizados no Quadro 5. Este quadro de referência para os investimentos no subsistema reflete medidas e metas previstas para o Complexo Industrial da Saúde no âmbito da política industrial. 
Quadro 5 - Perspectivas a médio prazo. Cenário possível - 2012

\begin{tabular}{|c|c|c|c|}
\hline $\begin{array}{l}\text { DETERMINANTES DA DINÂMICA } \\
\text { DO INVESTIMENTO ESPERADO }\end{array}$ & METAS PARA 2012 & $\begin{array}{l}\text { IMPACTOS NO SUBSISTEMA DAS } \\
\text { INDÚSTRIAS DE BASE QUIIMICA E } \\
\text { BIOTECNOLÓGICA }\end{array}$ & $\begin{array}{l}\text { EFEITOS ESPERADOS NO } \\
\text { CONJUNTO DA ECONOMIA }\end{array}$ \\
\hline $\begin{array}{l}\text { Manutenção do crescimento } \\
\text { do mercado farmacêutico } \\
\text { nacional e dos gastos } \\
\text { públicos em saúde. } \\
\text { Ampliação considerável do } \\
\text { mercado de medicamentos } \\
\text { genéricos mediante a } \\
\text { expiração de patentes de } \\
\text { medicamentos. } \\
\text { Câmbio operando como fator } \\
\text { de estímulo ao processo de } \\
\text { substituição de importações. } \\
\text { Criação de novos } \\
\text { mecanismos que promovam } \\
\text { a isonomia tributária } \\
\text { das importações frente } \\
\text { à produção nacional } \\
\text { (eliminação do viés pró- } \\
\text { importação). } \\
\text { Adequação do arcabouço } \\
\text { regulatório aos requerimentos } \\
\text { de promoção da inovação. }\end{array}$ & $\begin{array}{l}\text { Crescimento médio anual } \\
\text { do mercado farmacêutico } \\
\text { brasileiro entre } 8 \% \text { e } 11 \% \text {. } \\
\text { Aumento nos gastos públicos } \\
\text { em saúde para } 5 \% \text { do PIB. } \\
\text { Equilíbrio competitivo na } \\
\text { balança comercial (fármacos, } \\
\text { medicamentos, vacinas, } \\
\text { hemoderivados, reagentes e } \\
\text { toxinas). } \\
\text { Manutenção dos gastos em } \\
\text { P\&D no setor farmacêutico } \\
\text { em torno } 2 \% \text { da RLV. } \\
\text { Desenvolvimento de } \\
\text { tecnologia para produção } \\
\text { nacional de vinte principais } \\
\text { medicamentos e insumos da } \\
\text { lista de produtos estratégicos } \\
\text { no âmbito do SUS. }\end{array}$ & $\begin{array}{l}\text { Aumento na capacidade } \\
\text { produtiva associada com } \\
\text { aumento na escala de } \\
\text { produção. } \\
\text { Consolidação patrimonial } \\
\text { de empresas farmacêuticas } \\
\text { nacionais, particularmente no } \\
\text { segmento de genéricos. } \\
\text { Redução no déficit na balança } \\
\text { comercial de fármacos e } \\
\text { medicamentos. } \\
\text { Aumento na capacitação } \\
\text { de empresas para inovação } \\
\text { incremental. } \\
\text { Fortalecimento do sistema } \\
\text { nacional de inovação em } \\
\text { saúde e sua maior articulação } \\
\text { com o sistema de saúde. }\end{array}$ & $\begin{array}{l}\text { Expansão do PIB e geração de } \\
\text { emprego. } \\
\text { Modernização da capacidade } \\
\text { produtiva e aumento da } \\
\text { produtividade. } \\
\text { Redução no déficit na balança } \\
\text { comercial no complexo da } \\
\text { saúde. } \\
\text { Desenvolvimento tecnológico } \\
\text { e industrial/capacitação } \\
\text { inovativa em setores } \\
\text { estratégicos. } \\
\text { Aumento do dispêndio } \\
\text { em P\&D e com atividades } \\
\text { inovativas do setor privado. }\end{array}$ \\
\hline
\end{tabular}

Fonte: elaboração própria com base em Política de Desenvolvimento Produtivo - PDP (Brasil. Ministério do Desenvolvimento, Indústria e Comércio, 2008), Programa Mais Saúde (Brasil. Ministério da Saúde, 2007) e PAC da Inovação (Brasil. Ministério da Ciência, Tecnologia e Inovação, 2007).

Perspectivas a Longo Prazo: cenário desejável

De maneira geral, um dos principais objetivos estratégicos que se coloca a longo prazo no cenário do investimento na indústria farmacêutica consiste em vincular a ampliação da capacidade produtiva e de porte empresarial das empresas farmacêuticas nacionais com estratégias ativas de inovação e capacitação. A realização desse objetivo, entretanto, implica a superação de um conjunto considerável de desafios, conforme foi destacado na análise das tendências atuais e a médio prazo, apresentadas nas seções anteriores.

Um dos principais desafios que se vislumbra no cenário a longo prazo da indústria de base química e biotecnológica em saúde refere-se às condições de ingresso das empresas farmacêuticas e farmoquímicas nacionais na produção de medicamentos e fármacos a partir de rotas biotecnológicas. Apesar dos avanços recentes, a atuação dos laboratórios nacionais na produção de fármacos e medicamentos biológicos 
ainda é muito restrita e focada em produtos de primeira geração desenvolvidos, em sua maior parte, por laboratórios públicos a partir de contratos de transferência de tecnologia com laboratórios multinacionais. Entre os laboratórios públicos com capacitação na produção de produtos biológicos destacam-se o Instituto Butantan em São Paulo e o Instituto de Tecnologia em Imunobiológicos da Fiocruz (BioManguinhos), no Rio de Janeiro.

Os produtos farmacêuticos oriundos de síntese química ainda respondem pela maior parte das receitas da indústria farmacêutica. Entretanto, produtos de origem biotecnológica não apenas figuram atualmente entre os medicamentos mais vendidos no mundo como também têm aumentado expressivamente sua participação relativa no mercado farmacêutico global. Estima-se que já em 2016 os produtos de origem biotecnológica deverão responder por aproximadamente $45 \%$ das vendas entre os cem principais produtos farmacêuticos no mercado global, ou o equivalente a US\$ 192 bilhões. Da mesma forma, estima-se que sete entre os dez produtos mais vendidos serão medicamentos biotecnológicos, entre os quais se destacam diferentes tipos de anticorpos monoclonais, proteínas terapêuticas e vacinas. Adicionalmente, no Brasil, a análise dos principais itens de déficit na balança comercial de fármacos e medicamentos no Brasil evidencia o peso elevado dos produtos de base biotecnológica na composição desse déficit, assim como no montante de compras públicas do MS.

Por um lado, a identificação da rota biotecnológica como um nicho estratégico para a produção de fármacos e medicamentos no país já se encontra contemplada tanto na política de desenvolvimento da base produtiva em saúde como no escopo das políticas de Ciência, Tecnologia e Inovação (CT\&I). No primeiro caso destaca-se o conjunto de políticas que têm sido implementadas com base nas proposições do Grupo Executivo do Complexo Industrial da Saúde (Gecis), que contemplam ampla gama de ações voltadas para a modernização de plantas de laboratórios públicos e estímulos à internalização da produção de biofármacos estratégicos para o sistema de saúde. No segundo, caberia mencionar a própria Política de Desenvolvimento em Biotecnologia aprovada em 2007, que define alvos estratégicos, áreas prioritárias e áreas de fronteira para inovações radicais em biotecnologia. No caso das políticas de desenvolvimento da base produtiva em saúde, é possível identificar, entre as Parcerias para Desenvolvimento Produtivo (PDPs) em andamento, algumas iniciativas que envolvem a produção de biofármacos tais como os anticorpos monoclonais (adalimumabe), proteínas (betainterferona, fator VII recombinante e toxina botulínica) e enzimas (taliglucerase alfa). A análise sobre o alcance das ações do Gecis e a caracterização e detalhamento das PDPs serão apresentados na próxima seção.

Por outro lado, a busca de maior inserção na produção nacional de fármacos e medicamentos biológicos traz implicações em termos da construção de capacitações em áreas estratégicas nas quais o país ainda apresenta gargalos. A inserção em novas plataformas tecnológicas, particularmente no caso dos biofármacos de segunda geração, impõe o domínio de competências tecnológicas relacionadas a áreas como 
biologia molecular, epidemiologia, genômica, subtipos de doenças, biomarcadores etc. Ainda que o país já conte com recursos humanos qualificados em áreas como genômica e biologia molecular, há um consenso de que esses recursos ainda são escassos em etapas intermediárias do processo de desenvolvimento de fármacos e medicamentos como os estudos pré-clínicos e o escalonamento da produção (scaling-up) e produção de lotes piloto. Tal hiato dificulta a aproximação entre a academia e o setor produtivo e acaba por impedir que resultados da pesquisa possam ser convertidos em inovações de produto e processo na indústria. Ainda que tais limitações estejam presentes no desenvolvimento de produtos farmacêuticos a partir de síntese química, elas se tornam particularmente importantes para o segmento de medicamentos biológicos, dado o caráter ainda incipiente da produção de biofármacos no país.

As tendências no campo tecnológico têm se encaminhado para transformações significativas nas áreas de conhecimento e tecnologias associadas ao domínio da biotecnologia. Tais transformações decorrem da crescente integração e convergência entre diferentes plataformas como as de biologia molecular (genômica, proteômica etc.), bioinformática e bioimagem, nanobiotecnologia, ciências de materiais e sistemas de informação de alto desempenho. Essa convergência, além de alterar os padrões de demanda dos serviços de saúde e as tecnologias disponíveis para o seu atendimento, traz importantes implicações para o país em termos do investimento na formação de recursos humanos qualificados em novas áreas de conhecimento e tecnologias.

Na questão regulatória, em particular, é importante considerar que as mudanças no ciclo de $P \& D$ e desenvolvimento tecnológico de biofármacos têm implicações nos processos de comprovação de eficácia e segurança que se refletem diretamente na necessidade de adequação do marco regulatório.

Ainda que muitos desses desafios já venham sendo enfrentados conjuntamente no âmbito das políticas industrial e tecnológica e de saúde, é preciso aprofundar a análise sobre os condicionantes desse processo de reposicionamento da produção nacional de fármacos e medicamentos estratégicos, com vistas ao refinamento de sugestões para formulação e implementação de políticas.

A fim de sinalizar as perspectivas a longo prazo para o investimento no Subsistema de Base Química e Biotecnológica, parte-se, no Quadro 6, de uma análise dos efeitos desejáveis do investimento neste subsistema no horizonte de longo prazo para sinalizar os fatores determinantes de tal investimento e as transformações por ele engendradas. Ainda que leve em consideração o cenário mais favorável possível em termos de políticas setoriais, tal análise busca indicar as principais barreiras de ordem estrutural a serem superadas para que se promova o aumento do patamar competitivo do setor.

No quadro, procura-se sintetizar os principais elementos do cenário de investimento a longo prazo. Em linhas gerais, no tocante aos efeitos esperados dos investimentos neste setor sobre o conjunto da economia, ressalta-se inicialmente 
seu potencial de geração de emprego e expansão da renda. Conforme destacado, o CEIS como um todo responde atualmente por cerca de $9 \%$ do Produto Interno Bruto (PIB) e por mais de nove milhões de empregos diretos e indiretos. Tendo em vista a expressiva participação do segmento farmacêutico e farmoquímico na produção e na renda geradas nesse complexo, é plausível estimar um impacto elevado associado aos investimentos realizados neste subsistema.

Em segundo lugar, o elevado potencial científico e tecnológico dos diferentes segmentos de atividades relacionados ao setor farmacêutico torna este subsistema um importante vetor de difusão de novos paradigmas tecnológicos na matriz produtiva brasileira. Tal percepção encontra-se presente na própria orientação da atual política industrial brasileira, que trata o Complexo Industrial da Saúde como um dos programas mobilizadores estratégicos.

Um terceiro e importante efeito decorrente dos investimentos neste subsistema está relacionado com a redução no desequilíbrio da balança comercial brasileira a partir da redução no déficit decorrente da importação de fármacos e medicamentos. Da mesma forma, associada à redução do déficit comercial, encontra-se a ampliação e diversificação das exportações brasileiras, tendo em vista o foco em produtos de maior valor agregado e conteúdo tecnológico.

Os impactos esperados dos investimentos sobre o subsistema, bem como os determinantes necessários para que esse processo de transformação estrutural seja viável a longo prazo, também se encontram sintetizados no Quadro 6.

Quadro 6 - Perspectivas a longo prazo. Cenário desejável - 2022

\begin{tabular}{|c|c|c|c|}
\hline $\begin{array}{l}\text { DETERMINANTES DA DINÂMICA } \\
\text { DO INVESTIMENTO ESPERADO }\end{array}$ & METAS PARA 2022 & $\begin{array}{l}\text { IMPACTOS NO SUBSISTEMA DAS } \\
\text { INDÚSTRIAS DE BASE QUIIMICA E } \\
\text { BIOTECNOLÓGICA }\end{array}$ & $\begin{array}{l}\text { EFEITOS ESPERADOS NO } \\
\text { CONJUNTO DA ECONOMIA }\end{array}$ \\
\hline $\begin{array}{l}\text { Expansão e recomposição } \\
\text { da participação pública nos } \\
\text { gastos em medicamentos. } \\
\text { Ampliação e consolidação } \\
\text { da infraestrutura tecnológica } \\
\text { de apoio à inovação nos } \\
\text { segmentos do CEIS. } \\
\text { Câmbio operando como fator } \\
\text { de estímulo ao processo de } \\
\text { substituição de importações. } \\
\text { Estímulo continuado à } \\
\text { pesquisa e à inovação na } \\
\text { produção de medicamentos } \\
\text { negligenciados e de suas } \\
\text { matérias-primas. }\end{array}$ & $\begin{array}{l}\text { Aumento nos gastos públicos } \\
\text { em saúde para } 7 \% \text { do PIB. } \\
\text { Crescimento médio anual } \\
\text { do mercado farmacêutico } \\
\text { brasileiro entre } 8 \% \text { e } 11 \% \text {. } \\
\text { Equilíbrio competitivo na } \\
\text { balança comercial (fármacos, } \\
\text { medicamentos, vacinas, } \\
\text { hemoderivados, reagentes e } \\
\text { toxinas). } \\
\text { Ampliação dos gastos em } \\
\text { P\&D no setor farmacêutico } \\
\text { para } 8 \% \text { da RLV. }\end{array}$ & $\begin{array}{l}\text { Aumento na capacidade } \\
\text { produtiva associada com } \\
\text { aumento na escala de } \\
\text { produção e diversificação } \\
\text { em produtos de maior valor } \\
\text { agregado. } \\
\text { Aumento da participação } \\
\text { relativa do segmento } \\
\text { farmoquímico na indústria } \\
\text { farmacêutica. } \\
\text { Aumento da participação } \\
\text { brasileira no esforço } \\
\text { global de P\&D da indústria } \\
\text { farmacêutica. }\end{array}$ & $\begin{array}{l}\text { Expansão do PIB e geração de } \\
\text { emprego. } \\
\text { Modernização da capacidade } \\
\text { produtiva e aumento da } \\
\text { produtividade. } \\
\text { Desenvolvimento tecnológico } \\
\text { e industrial/capacitação } \\
\text { inovativa em setores } \\
\text { estratégicos. } \\
\text { Aumento do dispêndio } \\
\text { em P\&D e com atividades } \\
\text { inovativas do setor privado. }\end{array}$ \\
\hline
\end{tabular}


Quadro 6 - Perspectivas a longo prazo. Cenário desejável - 2022 ( continuação )

\begin{tabular}{|c|c|c|c|}
\hline $\begin{array}{l}\text { DETERMINANTES DA DINÂMICA } \\
\text { DO INVESTIMENTO ESPERADO }\end{array}$ & METAS PARA 2022 & $\begin{array}{l}\text { IMPACTOS NO SUBSISTEMA DAS } \\
\text { INDÚSTRIAS DE BASE QUIMICA E } \\
\text { BIOTECNOLÓGICA }\end{array}$ & $\begin{array}{l}\text { EFEITOS ESPERADOS NO } \\
\text { CONJUNTO DA ECONOMIA }\end{array}$ \\
\hline $\begin{array}{l}\text { Adequação do arcabouço } \\
\text { regulatório aos requerimentos } \\
\text { de promoção da inovação } \\
\text { (vigilância sanitária, } \\
\text { propriedade intelectual, } \\
\text { uso sustentável da } \\
\text { biodiversidade, política de } \\
\text { preços e carga tributária). } \\
\text { Criação de novos } \\
\text { mecanismos que promovam } \\
\text { a isonomia tributária das } \\
\text { importações em relação } \\
\text { à produção nacional } \\
\text { (eliminação do viés pró- } \\
\text { importação). }\end{array}$ & $\begin{array}{l}\text { Desenvolvimento de } \\
\text { tecnologia para produção } \\
\text { nacional da lista de produtos } \\
\text { estratégicos no âmbito do } \\
\text { SUS. }\end{array}$ & $\begin{array}{l}\text { Consolidação do Brasil como } \\
\text { principal polo da indústria } \\
\text { farmacêutica na América } \\
\text { Latina. } \\
\text { Nacionalização da produção } \\
\text { de insumos farmoquímicos } \\
\text { e medicamentos de maior } \\
\text { impacto no sistema nacional } \\
\text { de saúde. } \\
\text { Redução significativa do } \\
\text { déficit na balança comercial } \\
\text { de fármacos e medicamentos. } \\
\text { Fortalecimento do sistema } \\
\text { nacional de inovação em } \\
\text { saúde e sua maior articulação } \\
\text { com o sistema de saúde. }\end{array}$ & $\begin{array}{l}\text { Redução no déficit na balança } \\
\text { comercial no complexo da } \\
\text { saúde. } \\
\text { Ampliação e diversificação } \\
\text { das exportações brasileiras. }\end{array}$ \\
\hline
\end{tabular}

Fonte: elaboração própria.

\section{CONSIDERAÇÕES FINAIS E PROPOSIÇÕES DE POLÍTICAS}

Desde a Política Industrial, Tecnológica e de Comércio Exterior (PITCE), lançada em 2003, o setor farmacêutico foi selecionado como uma das áreas estratégicas para o futuro, o que motivou a priorização, no âmbito das políticas, do orçamento público e dos financiamentos das agências de fomento, com destaque para o BNDES e a Financiadora de Estudos e Projetos (Finep) (BRASIL. Ministério do Desenvolvimento, Indústria e Comércio, 2003). No presente, com a ampliação do escopo para o CEIS, o setor foi incluído como prioridade pela Política de Desenvolvimento Produtivo (PDP/ PR), pelo Mais Saúde (PAC-Saúde/MS), pelo PAC da Inovação (do MCTI) e nas diversas ações estruturantes previstas no Plano Brasil Maior.

Essa crescente articulação entre a política industrial e tecnológica e a área da saúde, associada ao processo de retomada dessas políticas ao longo da última década, reflete o reconhecimento da larga interface da saúde com as novas plataformas tecnológicas ligadas à biotecnologia, nanotecnologia e química fina avançada, e de sua importância na base produtiva industrial.

Dentre as novas diretrizes que colocam a saúde como espaço estratégico de política destacam-se em particular o uso do poder de compra do Estado, o aprimoramento do marco regulatório com vistas ao apoio à inovação e o estabelecimento de novos instrumentos de financiamento ao setor produtivo mediante parcerias para o 
desenvolvimento produtivo que envolvam a participação dos institutos públicos de pesquisa no domínio de novas plataformas tecnológicas.

Quanto ao uso do poder de compra, é possível destacar um conjunto de medidas e instrumentos que visam a aliar a consolidação da base produtiva em saúde com o desenvolvimento de produtos com maior valor agregado e conteúdo tecnológico. Tais medidas incluem a publicação da lista de produtos prioritários para o SUS (Portaria 1.284 de 2010), a nova Lei de Compras Públicas que deverá contemplar uma margem de preferência para fármacos e medicamentos estratégicos produzidos no Brasil, e as Parcerias para Desenvolvimento Produtivo (PDPs) envolvendo laboratórios oficiais e privados.

A lista de produtos prioritários, regulamentada pela Portaria 978 de 2008 e atualizada pela Portaria 1.284 de 2010 , relaciona os produtos que constituem foco prioritário para o aumento da produção local, seja por sua elevada importância social e econômica, seja por sua relevância na busca de novas capacitações tecnológicas na área da saúde.

A regulamentação da Lei 12.349 (Lei de Compras Públicas), por sua vez, prevê a utilização, de forma escalonada, de uma margem de preferência (de no máximo $25 \%)$ para licitação de produtos manufaturados e serviços nacionais resultantes de desenvolvimento e inovações tecnológicas realizadas no país. No caso específico de fármacos e medicamentos estratégicos, foram selecionados três grandes grupos de produtos estratégicos que podem ser classificados em seis tipos, de acordo com o grau de integração produtiva e intensidade tecnológica. Com base nessa classificação, a Comissão Interministerial de Compras Públicas (CICP) sugeriu a aplicação das seguintes margens de preferência e prazo de vigência para os diferentes grupos de produtos:

- Grupo I - dez medicamentos nacionais que utilizam fármaco importado na sua formulação; margem de preferência de $8 \%$.

- Grupo II - 34 medicamentos nacionais que utilizam fármaco nacional na sua formulação; margem de preferência de $20 \%$.

- Grupo III - 34 fármacos nacionais; margem de preferência de 20\%.

- Grupo IV - quatro insumos farmacêuticos não ativos (adjuvantes) nacionais; margem de preferência de $20 \%$.

- Grupo V-22 medicamentos nacionais que utilizam em sua formulação biofármaco com produção tecnológica integrada no país; margem de preferência normal de $20 \%$ e margem adicional de $5 \%$.

- Grupo VI - 22 biofármacos com produção tecnológica integrada no país; margem de preferência normal de $20 \%$ e margem adicional de $5 \%$.

- Finalmente, as PDPs são uma iniciativa recente do MS que visa prioritariamente a: i) ampliar a capacidade de regulação dos preços de produtos adquiridos pelos 
SUS; ii) internalizar a tecnologia de produção de fármacos nos laboratórios públicos mediante processos de transferência de tecnologia; iii) estimular a produção local de produtos de alto custo e/ou grande impacto sanitário e social.

O estabelecimento dessas parcerias envolve a associação de pelo menos um laboratório público com um laboratório privado, queéresponsável pelo desenvolvimento e transferência de tecnologia de produção para o primeiro. Além disso, a parceria envolve a participação de uma empresa farmoquímica, responsável pela internalização da produção do IFA. Assim, a partir da PDP tem-se o desenvolvimento do medicamento novo e seu insumo farmacêutico ativo no país, a transferência de tecnologia para o laboratório público, a obtenção de registro concedido pela agência reguladora e a disponibilização de medicamentos a preços inferiores aos anteriormente pagos nas aquisições públicas realizadas pelo MS.

Entre 2009 e 2011 foram aprovadas 31 parcerias com a participação de 11 laboratórios públicos e 22 laboratórios privados para a fabricação de 29 produtos acabados (28 medicamentos, um produto para saúde e um kit diagnóstico).

As PDPs representam, portanto, um poderoso instrumento de incentivo à produção e inovação em medicamentos estratégicos, além de operar na regulação de preços desses medicamentos. Da mesma forma, tal como está estruturada essa iniciativa difere do modelo tradicional de parcerias público-privadas, em que ocorre a transferência da coordenação do processo de produção e inovação para o setor privado.

Entretanto, por se tratar de uma iniciativa relativamente recente e ainda em fase de estruturação, o alcance e a efetividade desse instrumento ainda devem ser objeto de avaliação. Das 31 parcerias estabelecidas até o momento, apenas oito já se encontram com o registro do medicamento na Anvisa. Da mesma forma, as principais diretrizes para o estabelecimento das PDPs foram definidas recentemente na Portaria 837, de abril de 2012.

Dentre os fatores que devem ser considerados na avaliação das PDPs, o principal é a capacidade de modernização dos laboratórios públicos para adequação da estrutura fabril a processos produtivos de maior complexidade. O Brasil conta, hoje, com uma rede de 21 laboratórios públicos que, estando ligados ao MS, produzem medicamentos, soros e vacinas para atender às necessidades dos programas do SUS. Além de terem ampla abrangência nacional, esses laboratórios respondem hoje pela produção de $80 \%$ das vacinas e $30 \%$ dos medicamentos utilizados no SUS; muitos desses produtos não constituem foco de interesse de laboratórios privados, por se aplicarem a doenças negligenciadas como malária, esquistossomose ou doença de Chagas. Entretanto, além de modelos jurídicos diversos, esse grupo de laboratório apresenta diferenças significativas em termos de capacidade produtiva e domínio tecnológico. A maior parte desses laboratórios apresenta problemas de ociosidade fabril e adequação de suas instalações às BPFs exigidas pela Anvisa. Alguns poucos laboratórios oficiais se destacam pelo domínio de competências tecnológicas na produção de vacinas e 
outros biofármacos, como é o caso de Bio-Manguinhos e do Instituto Butantan. Nesse contexto, a fim de viabilizar o sucesso dos processos de internalização de medicamentos estratégicos por meio das PDPs, fica evidente a necessidade de implementação de uma política específica de investimentos nos laboratórios públicos visando à modernização da gestão e à qualificação dos seus quadros.

Na realidade, verifica-se que essas políticas de apoio aos laboratórios públicos já estão sendo colocadas em prática com iniciativas como o Programa de Modernização Produtiva e Gerencial de Produtores Públicos de Medicamentos e Imunobiológicos do MS ou o Programa BNDES-Profarma-Produtores Públicos.

No caso da base produtiva do CEIS verifica-se, de maneira geral, que o seu desenvolvimento encontra-se hoje amplamente respaldado por uma série de ações de promoção do Complexo Industrial da Saúde (CIS) coordenadas a partir da SCTIE no MS e no âmbito das instituições que integram o Gecis.

o Gecis foi criado pelo Decreto Presidencial de 12 de maio de 2008, com o objetivo de articular ações de incentivo ao CIS e incentivar a produção e inovação em saúde no país, com vistas ao aumento de sua competitividade nos mercados interno e externo. Tais ações envolvem o uso do poder de compra do SUS como forma de indução do aumento da produção e inovação no CIS. Em 2011, o Gecis foi incorporado como Comitê Executivo do Complexo da Saúde no Plano Brasil Maior.

No âmbito das ações de incentivo, um dos eixos que devem pautar a expansão do investimento na indústria farmacêutica nacional encontra-se associado ao papel de programas de apoio ao financiamento das empresas do setor que contemplem tanto a expansão da capacidade produtiva como a consolidação de competências para inovar.

Destaca-se, em particular, a importância que assume o desdobramento do Profarma/ BNDES como programa de apoio ao desenvolvimento do CIS. O Profarma divide-se em cinco subprogramas: Produção, Exportação, Inovação, Reestruturação e Produtores Públicos. Com essas linhas de atuação, o programa visa a apoiar o investimento no complexo de saúde, com o objetivo explícito de articular a PDP e a PNS.

O Profarma foi criado em 2004 como um dos instrumentos da PITCE para apoio ao setor farmacêutico e, desde então, já foi reestruturado duas vezes. No mais recente processo de reestruturação (maio de 2012), o programa elevou a sua carteira para $\mathrm{R} \$ 5$ bilhões. Esses recursos estarão disponíveis até 2016 para financiar projetos de inovação e expansão das indústrias farmacêuticas instaladas no país.

Até abril de 2012 a carteira do Profarma totalizava $R \$ 3,5$ bilhões, dos quais $\mathrm{R} \$ 2,097$ bilhões já estavam comprometidos com financiamentos para o setor. Em 2011, os projetos de inovação ultrapassaram os de produção, pela primeira vez desde o início do programa. Em 2011, os desembolsos para inovação ficaram em 50\% do total, ao passo que os de produção ficaram em $39 \%$. 
No âmbito das ações estratégicas de incentivo no campo da ciência, tecnologia e inovação, cabe destacar o papel do Fundo Setorial, o CT-Saúde, e o programa de subvenção econômica às empresas, cujos objetivos envolvem, entre outros, a capacitação tecnológica nas áreas de interesse do SUS e o estímulo ao aumento dos investimentos privados em $P \& D$ na área da saúde. A área farmacêutica é uma das principais em termos de projetos aprovados.

No tocante ao ambiente de regulação, a partir da segunda metade da década de 90 as transformações mais importantes no ambiente regulatório do setor farmacêutico no Brasil estiveram relacionadas de modo destacado com o estabelecimento da nova Lei de Propriedade Intelectual em 1996 (Lei 9.772), com a criação da Anvisa em 1999 (Lei 9.782) e com a Lei dos Medicamentos Genéricos de 1999 (Lei 9.787), que, como mencionado, talvez tenha sido, em conjunto com o Profarma, o fator crucial para o aumento da participação das empresas nacionais na indústria.

Uma das principais restrições atribuídas ao marco regulatório atualmente se refere à demanda de isonomia sanitária por parte de produtores nacionais que alegam a falta de controle e inspeção sanitária de IFAs importados da China e da Índia: enquanto os produtores nacionais estariam submetidos a rigorosas inspeções de BPFs e a outros instrumentos de controle sanitário (licença estadual e inspeções, por exemplo), os produtores estrangeiros não passam por processos e gastos semelhantes. A Anvisa implantou, recentemente, um processo de inspeções para as empresas produtoras estrangeiras e a exigência de registro de fármacos. O registro de IFAs no Brasil é regulamentado pela Resolução da Diretoria Colegiada (RDC) 57/2009 da Anvisa, porém essa norma ainda tem aplicação limitada, pois contempla a exigência de registro sanitário para uma lista de apenas vinte IFAs, de acordo com a Instrução Normativa 15/2009, o que é considerado insuficiente pelas empresas do setor. Cabe ressaltar que o processo de registro de IFA no Brasil implica a inspeção para fins de certificação de BPFs das empresas produtoras localizadas no exterior, porém a Anvisa não conta hoje com uma estrutura capaz de garantir esse tipo de controle.

No que se refere aos produtos biológicos, um dos principais pontos de debate quanto à sua produção reside no fato de serem esses medicamentos muito mais complexos do que aqueles produzidos por síntese química, tanto em termos da sua estrutura como em termos dos processos produtivos associados. Assim, há controvérsias quanto à comparabilidade e equivalência em termos de eficácia e segurança. O estabelecimento de diretrizes regulatórias gerais para os medicamentos biológicos no Brasil é recente, mas o registro de produtos biológicos já conta com uma normativa da Anvisa, a RDC 55/2010 que diferencia duas categorias de produtos biológicos e biotecnológicos no Brasil: i) os produtos inovadores, denominados produtos biológicos novos; ii) as cópias, denominadas produtos biológicos. Os registros dos produtos biológicos novos seguem, necessariamente, a via regulatória clássica, com apresentação de dossiê completo, contendo todos os dados de produção, controle de qualidade e dados completos sobre ensaios não clínicos e 
clínicos. Para os produtos biológicos, ou seja, os produtos não inovadores, há duas vias regulatórias possíveis para registro: a via de desenvolvimento por comparabilidade e a via de desenvolvimento individual. Nessas duas vias é possível apresentar um dossiê de registro com informações reduzidas. Aliado ao esforço de criar um arcabouço regulatório adequado, a Anvisa tem procurado avançar na criação de instrumentos e instâncias de suporte que permitam reduzir o tempo de registro de produtos considerados prioritários pelo MS. Tal processo passa pela criação de comitês regulatórios para acompanhamento das etapas de desenvolvimento de medicamentos biotecnológicos nas empresas e pela criação de uma câmara setorial e de uma câmara técnica de biotecnologia.

Apesar dos avanços que parecem estar ocorrendo nos procedimentos de registro de medicamentos biotecnológicos, há gargalos a serem desobstruídos no campo da propriedade intelectual relacionados ao registro de patentes de medicamentos biológicos. A legislação sobre patentes hoje em vigor no Brasil não considera patenteáveis genes, substâncias produzidas por um microrganismo em estado natural, sementes, extratos ou células de plantas e animais em estado natural, moléculas e microrganismos isolados da natureza. Assim, mesmo com a garantia de patenteamento de produtos provenientes de processos biotecnológicos, subsistem dúvidas quanto à proteção patentária para determinadas linhagens celulares produtoras.

No campo da pesquisa biotecnológica em particular, verifica-se a existência de sérias restrições na regulamentação, o que inibe o investimento em biotecnologia por parte do setor produtivo. A lei atual prevê a exigência de pelo menos três tipos de autorização para o início de um projeto de pesquisa sobre a biodiversidade brasileira, relativas: i) à pesquisa científica; ii) à bioprospecção e desenvolvimento; iii) ao acesso ao conhecimento tradicional. Tal situação resulta tanto na dificuldade de dar início a estudos na área como na impossibilidade de regularizar estudos já feitos.

Assim, a revisão do marco regulatório relativo ao acesso ao patrimônio genético e propriedade intelectual deveria contemplar mudanças que dizem respeito, entre outros, a: acesso; uso e remessa de material do genoma humano; patrimônio genético; farmacogenômica; propriedade intelectual; biossegurança; bioética e fertilização assistida.

\section{Proposições de Políticas}

Com base no conjunto de evidências aqui examinadas, apresenta-se a seguir uma síntese das principais recomendações que visam a subsidiar, no nível estratégico, a formulação e implementação de programas e políticas públicas para fortalecer os diferentes segmentos do Subsistema de Base Química e Biotecnológica:

- Coerência das políticas e instrumentos com o estágio de desenvolvimento deste subsistema no Brasil, sendo estratégico o fortalecimento da base de produtiva e de inovações incrementais que deem sustentabilidade empresarial para a entrada progressiva em projetos mais radicais de inovação, superando visões estanques e ineficazes que cindem as capacidades produtiva e de inovação. 
- Consolidação e aprofundamento das iniciativas em curso para a constituição de um marco regulatório favorável ao subsistema, envolvendo e articulando tanto o aumento da capacidade produtiva e empresarial quanto o estímulo às inovações incrementais e radicais, destacando-se:

i. uma forte e generalizada utilização estratégica do poder de compra do Estado, estimulando, de forma clara e incisiva, a produção e a inovação local e sua articulação com as necessidades de saúde;

ii. a modernização e uso estratégico da regulação sanitária, buscando aliar segurança e eficácia ao desenvolvimento produtivo nacional;

iii.um regime de propriedade intelectual favorável ao estágio incremental das inovações neste subsistema, tomando o Trips como teto e aproveitando todas as flexibilidades para atenuar as práticas oligopólicas que restringem a difusão de inovações;

iv. um regime tributário que favoreça a expansão do mercado interno via redução dos preços e fortalecimento dos gastos públicos, com foco nos produtos de maior importância para o SUS e de maior densidade tecnológica;

v. ação para que a política de controle e regulação de preços articule a estratégia de garantia de ampliação do acesso com a de inovação.

- Priorização das atividades de inovação incremental e radical no âmbito de todos os incentivos financeiros e fiscais, evitando o risco de se trabalhar com um conceito de inovação restrito e inadequado no estágio atual do subsistema.

- Adoção de mecanismos inovadores de fomento e criação de inovações financeiras para atenuar o risco tecnológico que permitam superar as barreiras para a consolidação de grandes empresas nacionais e para o estabelecimento e fortalecimento de arranjos produtivos entre produtores públicos e pequenas e médias empresas de produtos intensivos em conhecimento (farmoquímicos, reagentes para diagnóstico etc.), procurando-se agregar uma visão estratégica às práticas e análises econômico-financeiras e contábeis nos mecanismos de financiamento de sistemas produtivos estratégicos para o futuro.

- Criação de estímulos para adensamento da cadeia produtiva do setor farmacêutico em atividades de alta densidade tecnológica, envolvendo verticalizações seletivas da produção para produtos de base química e biotecnológica.

- Criação de mecanismos para estimular a conformação de uma estrutura de suporte à inovação na empresa, adequando as instituições a uma lógica produtiva e industrial e não acadêmica, envolvendo, por exemplo, mecanismos para flexibilidade organizacional na rede de serviços tecnológicos e de pesquisa pré-clínica e clínica para favorecer a interação com o setor produtivo em plataformas tecnológicas estratégicas para o futuro. 
- Fortalecimento da rede de laboratórios públicos por meio do aprofundamento e consolidação dos novos mecanismos de estímulo às parcerias público-privadas, incorporando uma lógica local e regional na estratégia de inovação nos segmentos de base química e biotecnológica.

Finalmente, não obstante as dificuldades de implementação e de coordenação inerentes às novas políticas, instrumentos e ações para o Subsistema de Base Química e Biotecnológica, percebe-se atualmente um movimento bastante promissor de convergência da Política Industrial e Tecnológica com a Política de Saúde. Tal articulação é crucial para o sucesso de qualquer estratégia de desenvolvimento do setor e permite aliar a inovação à demanda social.

o Quadro 7 permite apreender de modo analítico e bastante sintético as modalidades de instrumentos, envolvendo incentivos, regulação e coordenação segundo a natureza dos investimentos a serem apoiados.

Quadro 7 - Proposição de políticas. Síntese

\begin{tabular}{|c|c|c|c|c|}
\hline \multicolumn{5}{|c|}{ TIPOS DE INSTRUMENTO } \\
\hline & & INCENTIVOS & REGULAÇÃO & COORDENAÇÃO \\
\hline 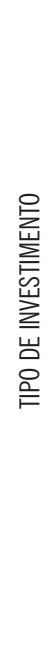 & INDUZIDO & $\begin{array}{l}\text { Incentivos financeiros } \\
\text { e fiscais para ampliar o } \\
\text { investimento em expansão da } \\
\text { capacidade produtiva. } \\
\text { Articulação da produção } \\
\text { pública com o estímulo à } \\
\text { expansão da capacidade } \\
\text { produtiva do setor privado } \\
\text { nacional. } \\
\text { Uso do poder de compra } \\
\text { do Estado para aumentar } \\
\text { a capacidade produtiva e } \\
\text { de inovação incremental no } \\
\text { subsistema. }\end{array}$ & $\begin{array}{l}\text { Aprofundamento da revisão } \\
\text { do marco regulatório com } \\
\text { vistas à sua adequação para } \\
\text { articular o atendimento das } \\
\text { necessidades de saúde com } \\
0 \text { aumento da capacidade } \\
\text { produtiva e de inovações } \\
\text { incrementais (regulação } \\
\text { sanitária, tributária, } \\
\text { da política de preços e } \\
\text { propriedade intelectual). } \\
\text { Amplo uso de todos os } \\
\text { mecanismos de flexibilização } \\
\text { do Trips (garantia do Trips } \\
\text { como 'teto'). } \\
\text { Revisão da política sanitária } \\
\text { a fim de impedir a importação } \\
\text { de insumos de baixa } \\
\text { qualidade. }\end{array}$ & $\begin{array}{l}\text { Consolidação e fortalecimento } \\
\text { do Gecis como instância } \\
\text { de articulação da política } \\
\text { industrial, de CT\&l e de saúde } \\
\text { para promover a capacidade } \\
\text { produtiva e de inovação } \\
\text { incremental. } \\
\text { Harmonização do sistema } \\
\text { de coordenaçãa regulatória } \\
\text { articulando competitividade } \\
\text { e proteção à saúde, inclusive } \\
\text { nas instâncias de regulação } \\
\text { sanitária e de propriedade } \\
\text { intelectual. }\end{array}$ \\
\hline
\end{tabular}


Quadro 7 - Proposição de políticas. Síntese ( continuação )

\begin{tabular}{|c|c|c|c|c|}
\hline \multicolumn{5}{|c|}{ TIPOS DE INSTRUMENTO } \\
\hline & & INCENTIVOS & REGULAÇÃO & COORDENAÇÃO \\
\hline 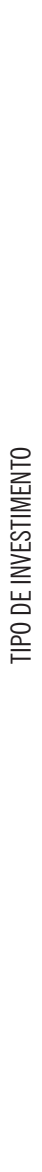 & ESTRATÉGICO & $\begin{array}{l}\text { Promoção da consolidação } \\
\text { patrimonial de empresas do } \\
\text { setor, visando ao aumento } \\
\text { de porte e de escala para } \\
\text { enfrentar a concorrência } \\
\text { global. } \\
\text { Uso estratégico do poder } \\
\text { de compra do Estado para } \\
\text { aumentar a capacidade } \\
\text { de inovação incremental e } \\
\text { radical no subsistema. } \\
\text { Uso articulado dos fundos de } \\
\text { CT\&l em saúde com outros } \\
\text { mecanismos de fomento } \\
\text { de projetos de pesquisa } \\
\text { cooperativa. } \\
\text { Criação de novos } \\
\text { instrumentos de fomento à } \\
\text { formação de redes de suporte } \\
\text { à inovação nas empresas. } \\
\text { Fortalecimento da } \\
\text { infraestrutura de serviços } \\
\text { tecnológicos com uma } \\
\text { estrutura de gestão } \\
\text { compatível com o setor } \\
\text { empresarial. } \\
\text { Estruturação de uma base } \\
\text { estatal de P\&D em saúde } \\
\text { fortemente articulada com as } \\
\text { necessidades de promoção } \\
\text { de um salto tecnológico do } \\
\text { setor produtivo nas novas } \\
\text { plataformas de fronteira. }\end{array}$ & $\begin{array}{l}\text { Revisão e adequação do } \\
\text { marco regulatório com } \\
\text { vista aos requerimentos de } \\
\text { aumento da capacidade de } \\
\text { inovação no subsistema com } \\
\text { foco na inovação incremental } \\
\text { e radical (regulação sanitária, } \\
\text { tributária, da política de } \\
\text { preços e propriedade } \\
\text { intelectual). } \\
\text { Aprofundamento e } \\
\text { aumento da velocidade na } \\
\text { modernização do sistema } \\
\text { nacional de vigilância } \\
\text { sanitária, adequando-0 aos } \\
\text { requerimentos da inovação } \\
\text { incremental e radical, sempre } \\
\text { obedecendo aos requisitos de } \\
\text { segurança e eficácia. } \\
\text { Adequação da proteção } \\
\text { da propriedade intelectual } \\
\text { em sintonia fina com a } \\
\text { capacidade local de inovação. }\end{array}$ & $\begin{array}{l}\text { Consolidação, fortalecimento } \\
\text { e ampliação do poder } \\
\text { decisório do Gecis como } \\
\text { instância de articulação da } \\
\text { política industrial, de CT\&l } \\
\text { e de saúde para promover } \\
\text { a capacidade produtiva, } \\
\text { a inovação incremental e } \\
\text { radical. } \\
\text { Harmonização do sistema } \\
\text { de coordenação regulatória } \\
\text { articulando competitividade } \\
\text { e proteção à saúde, com foco } \\
\text { na inovação. }\end{array}$ \\
\hline
\end{tabular}

CT\& - Ciência, Tecnologia e Inovação; Gecis - Grupo Executivo do Complexo Industrial da Saúde; P\&D - Pesquisa e Desenvolvimento; Trips - Acordo de Propriedade Intelectual.

Fonte: elaboração própria. 